537
$I 43$

opy 1

UNIVERSITY OF ILLINOIS BULLETIN Vol. XIV

MARCH 19, 1917

- No. 29

[Entored as second-class mattor December 11, 1912, at the post office at Urbang, Illinois, under the Act of August 24, 19:2.J

\title{
AGRICULTURE AT THE UNIVERSITY OF ILLINOIS
}

A STATEMENT OF THE WORK AND NEEDS OF THE COLLEGE OF AGRICULTURE AND AGRICULTURAL EXPERIMENT STATION

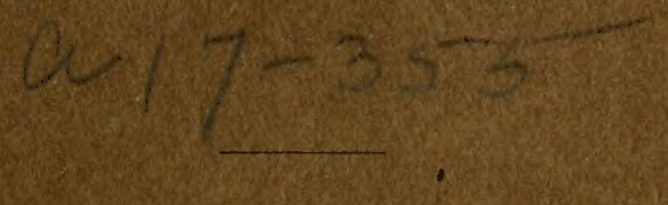

FOR THE INFORMATION OF

THE GOVERNOR

AND THE GENERAL ASSEMBLY

Bonograph

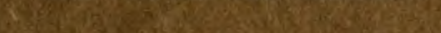

\begin{abstract}
Published by the University of Illinois
Usbana

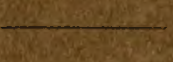

in 
$6 \times$ (2) 3 (2) (2)

ti.

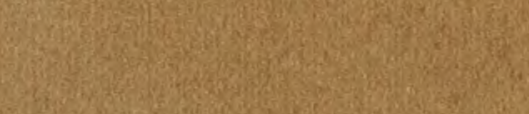

.

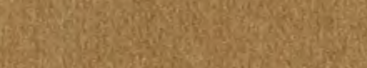

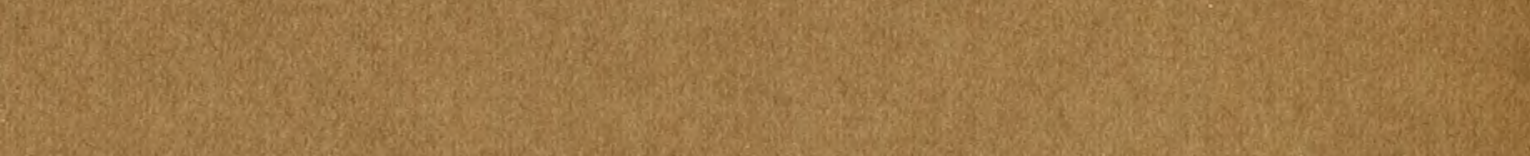

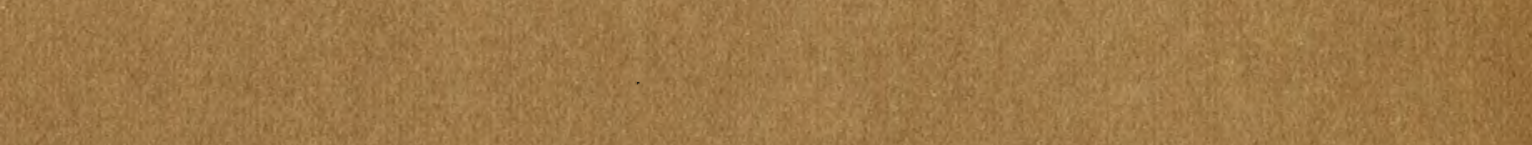
W.

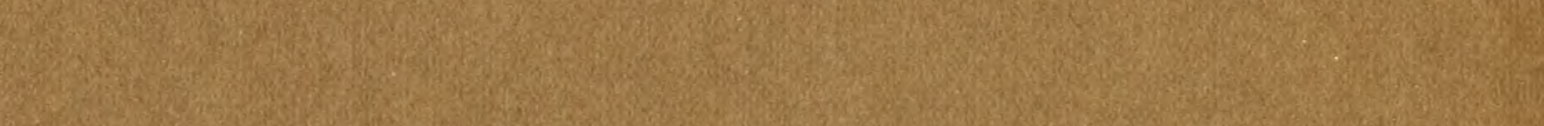
(5)

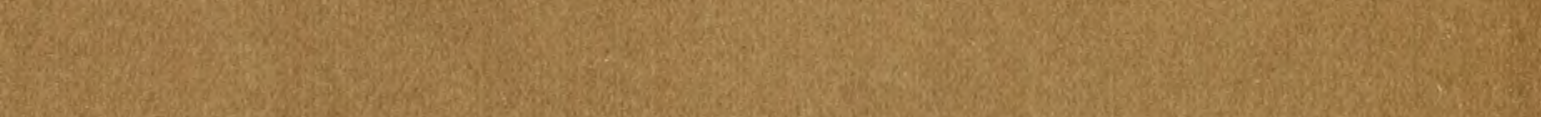
S.

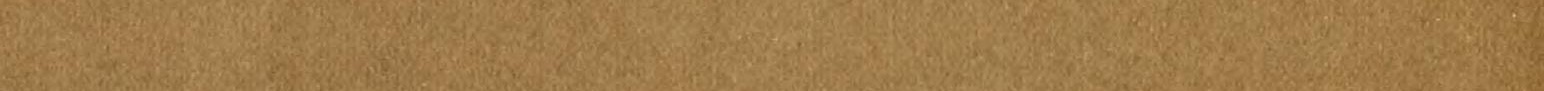
W.

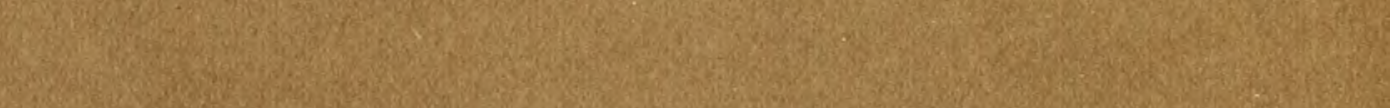

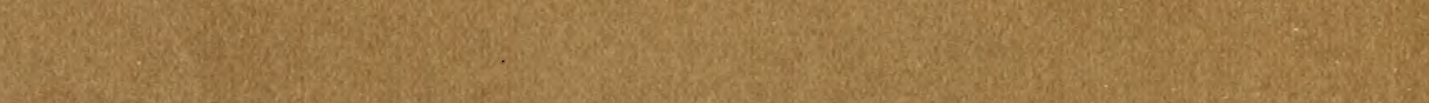

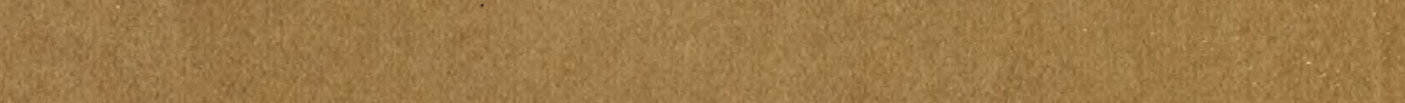
W. S.t. 2.

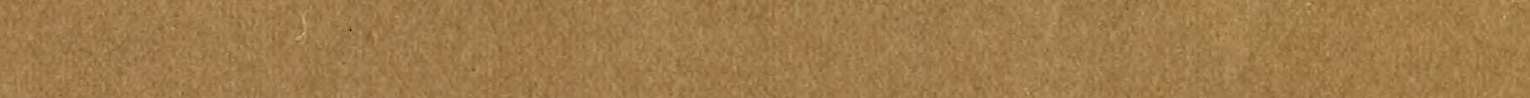

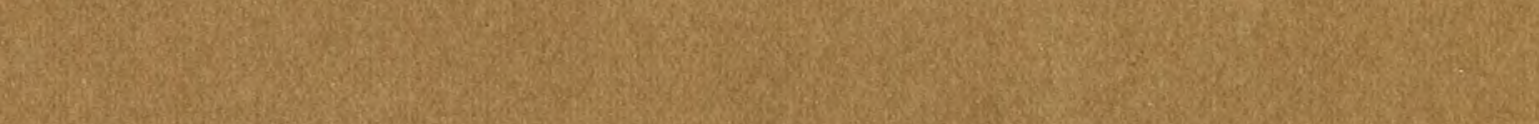
2.7. 


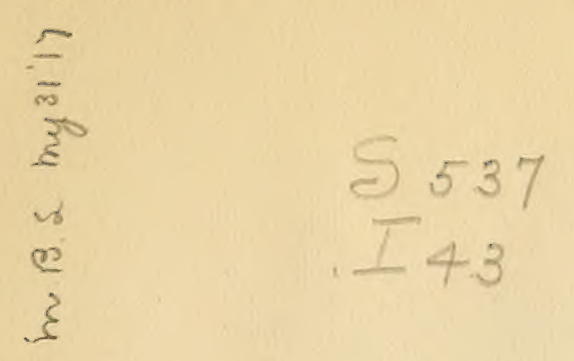




\title{
AGRICULTURE \\ AT THE UNIVERSITY OF ILLINOIS
}

\author{
A STATEMENT OF THE WORK AND NEEDS \\ OF THE COLLEGE OF AGRICULTURE AND \\ AGRICULTURAL EXPERIMENT STATION
}

Prepared by

the Dean and Heads of

Departments

URBANA - CHAMPAIGN

March, 1917 


\section{CONTENTS}

PAGE

WHERE THE GRADUATES GO AND WHAT THEY DO ............. 2

DEPARTMENTS OF-

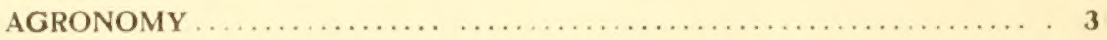

ANIMAL HUSBANDRY ................................... 7

DAIRY HUSBANDRY ................................... 15

HORTICULTURE.................................. 19

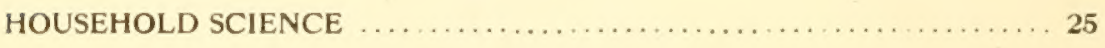

SMITH-LEVER EXTENSION .............................. 30

WHAT THE AGRICULTURAL COLLEGE AND EXPERIMENT STATION NEED 31

D. of D.

APR $\quad 2 \quad 1917$ 
This statement is prepared for the information of the Governor and General Assembly to show why the Agricultural College and Experiment Station are in need of larger resources and of a new Agricultural Building. 
The wealth of Illinois is in her soil, and her strength lies in its intelligent development.-Draper

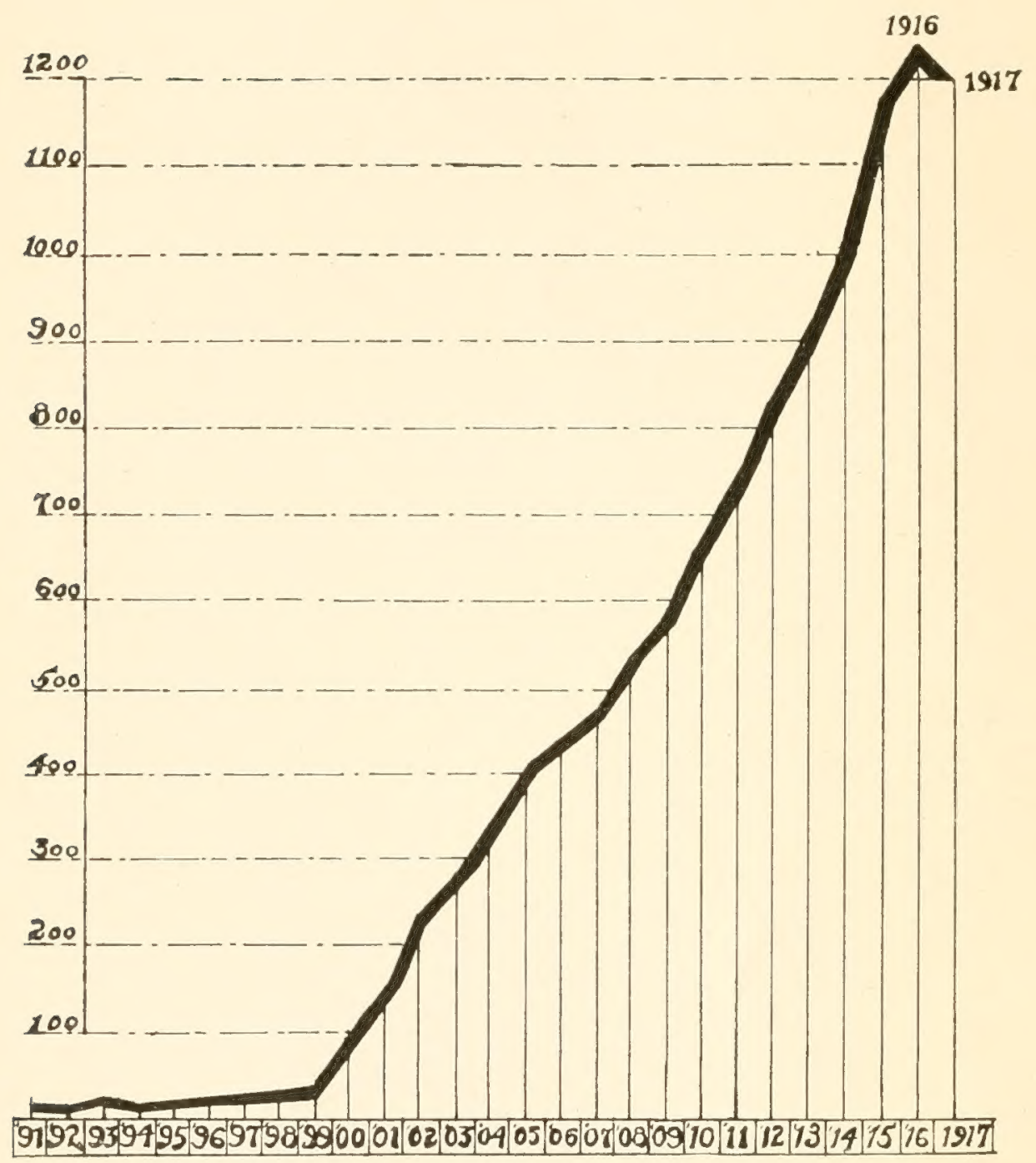

GROWTH IN STUDENT ATTENDANCE-COLLEGE OF AGRICULTURE, UNIVERSITY OF ILLINOIS, 1891-1917 


\section{AGRICULTURE AT THE UNIVERSITY OF ILLINOIS}

E. DAVENPORT, Dean of the COLlege of Agriculture AND DIRector of the Agricultural Experiment Station

$\mathrm{T}$

HE Agricultural College and Experiment Station were established for the advancement of farming and housekeeping and the improvement of living conditions in the open country. They are organized under six departments :

Agronomy - covering erops, soils, and farm mechanics

Animai, Husbandry-including horses, beef cattle, sheep, swine, meats, breeding, and feeding

DaIry Husbandry-dealing with dairy eattle, dairy farming, milk and its products

VetErinary Science--covering the general subject of animal diseases and their control

HORTICULTURE-ranging from orchard fruits and vegetable gardening to landscape gardening and floriculture

Housenold Science-treating of food, clothing, and shelter from the economic, the artistic, and the sanitary standpoints, especially in regard to the home

Each of these departments is organized to do work along three definite lines: (1) instruction of students, (2) investigation of unsolved problems, and (3) extension service to the people of the state outside the University. Besides these subject departments, there is maintained an extension service for young people of the state and a special cooperative demonstration service with farmers and housekeepers.

A brief statement of the work of the departments is given in the succeeding pages by the several heads and in the order named.

\section{THE STUDENT BODY}

Of the 1,201 students registered up to February 23, 1917, 992 come from the state of Illinois; 186 from other states; and 23 from foreign countries, these latter bringing to the University and the student body a rich variety of agricultural practices from other parts of the country and the world. The 992 students coming from Illinois represent every county of the state except 9 . The 209 coming from outside the state represent 36 states and 15 foreign countries.

Those coming direct from farms represent an average acreage of 275 , but many poor boys avail themselves of the college as a means of gratifying 
their desire to fit themselves for country life. One hundred and twenty-five, or 10 percent of the total number, come from Chicago, representing for the most part a pronounced and intelligent tide from the eity back to the land. Investigations show that this latter group of students is not headed for the teaching profession or for public jobs, but for the farm, and many of them come from land-holding families. It is therefore a type of student very much to be desired.

Of the total number, 1,015 express decided church preferences and represent 28 denominations. These students, as well as many not expressing a preference, connect themselves in various ways with local churches, the work of the Y.M. C. A. and the Y. W. C. A. and other religious organizations.

\section{WHERE THE GRADUATES GO AND WHAT THEY DO}

There have graduated from the Agricultural College of the University, 943 students since 1900 , and 53 before that date.

According to the latest available statisties, our graduates are engaged as follows:

69 percent are actually living upon farms and engaged in farming

17 percent are in agricultural departments of colleges, experiment stations, and high sehools

10 percent are in oceupations allied to farming, such as veterinary surgery, landseape gardening, creamery management, etc.

Less than 4 percent are in occupations not allied to agriculture

It has been said that the agricultural college is educating away from the land. These figures, which are about the same as those published by other and similar institutions, show how easy it is for an untruth to gain eireulation, especially when it is sensational. Clearly, the vast mass of our graduates follow the profession for which they are educated, and so far as our information goes, the proportion of non-graduates who return to the farm is even greater than these figures show, for the person who starts out to be a teacher must take his degree in order even to make a beginning; whereas, many farmers are able to take only one or two years of college work.

Nothing is clearer than that the Agricultural College of the University of Illinois is accomplishing the purpose for which it was organized. 



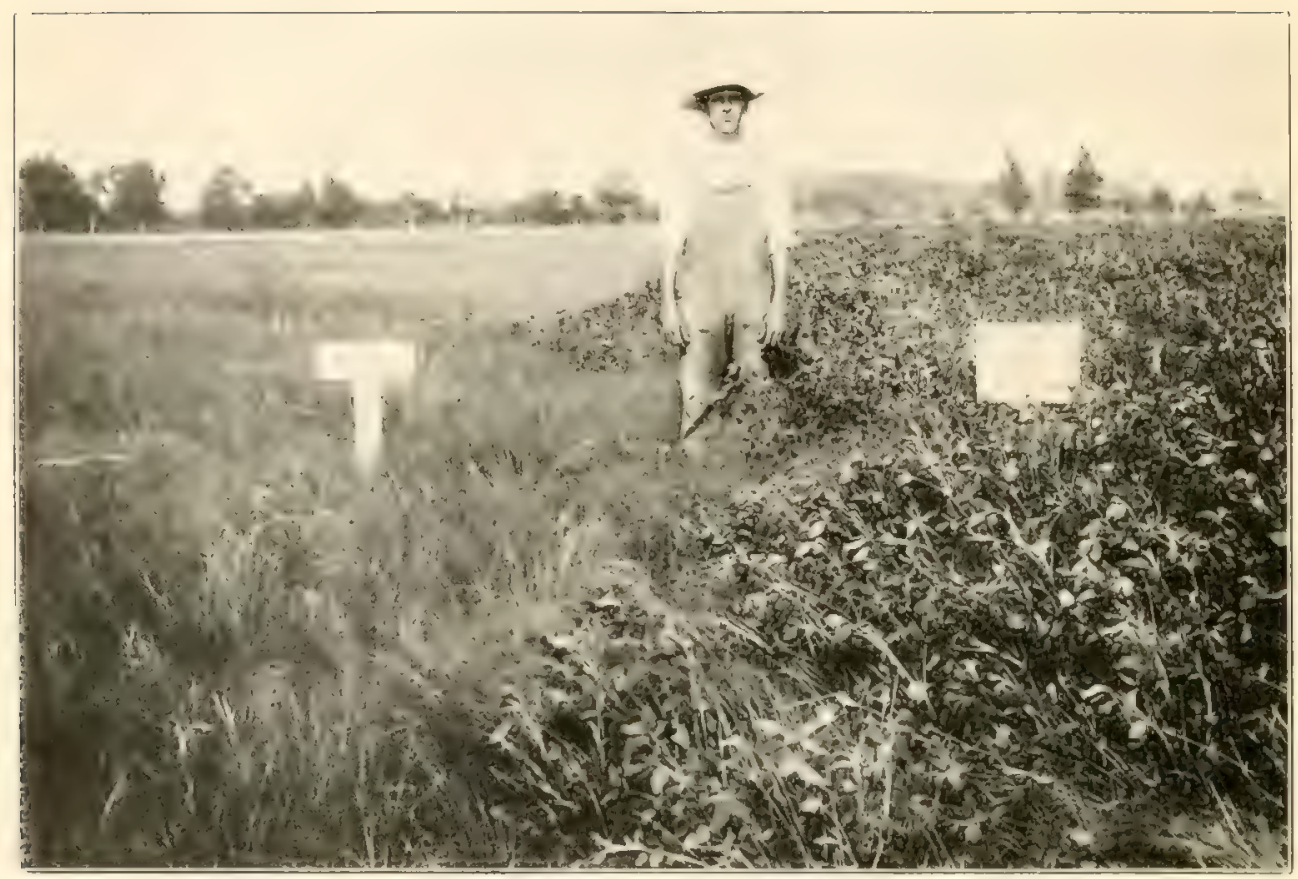

EFFECTS OF SOIL TREATMENT

Clover on Fairfield Experiment Field, 1910. Where manure alone was used, the first crop /shown in the photograph ) made about one-half ton of foul grass. with but little clover. Where the same amount of manure was used with limestone and phosphate, and with no potassium salts, the crop made nearly three tons of clean clover hay 


\title{
DEPARTMENT OF AGRONOMY
}

\author{
SOILS, FARM CROPS, AND FARM MECHANICS
}

Prepared by Cyril G. Hopkins, Head of Department

"The farm is the basis of all industry, but for many years this country has made the mistake of unduly assisting manufacture, commerce, and other activities that center in cities, at the expense of the farm."

These are the words of the late James J. Hill, himself a great railroad man, personally interested in commeree but fully alive to the meaning of agriculture.

One of the results of the carly neglect of agriculture is shown in the fact that from 1880 to 1910 , a period of one generation, $9,809,83+$ acres of "improved farm land" were agriculturally abandoned in New England. New York, New Jersey, and Pennsylvania, while the total areal of land still being farmed in 1910 was only $9,216,519$ acres in the eight states of $\mathrm{New}$ Hampshire, Vermont, Massachusets, Rhode Island, Commerticut, New Jersey, Deleware, and Florida. By this we see that New England and three states lying to the west have already abandoncd more land than is now farmed in seven of the thirteen original states with Florida added. This history of agriculture in our older eastern states must not be repeated in Illinois if we are to do our share in feeding our increasing population.

As agrieulture is the basic support of all industry, so the fertility of the soil, as measured by the production of staple crops, is the foundation of all success in agriculture.

The latest report of the United States Bureau of Census places the annual value of all Illinois farm and garden crops at $\$ 372,000,000$ of which the five great staple farm erops-com, oats, hay, wheat, and potatoes-. represent $\$ 345,000000$, or 93 percent of the total.

\section{UNIVERSITY WORK IN AGRONOMY}

The Department of Agronomy employs a force of more than forty teachers, investigators, and uxtension workers, besides the office and farm helpers. The annual applopriations used aggregate $\$ 174,800$, of which $\$ 98,500$, or more than half, is applied to the investigation of Illinois soils (tho this is less than 1 cent for every 3 acres of Illinois farm land, it is much more than any other state is devoting to the study of its soils); $\$ 20,000$ is available for investigations relating to farm erops; and $\$ 56,300$ for the instruction of students and for extension work in the general and special courses relating to soil physies and management, soil fertility, soil biology, crop production, crop improvement by plant breeding. land drainage, farm machinery, and farm buildings. (In addition, all soil reports, bulletins, and cincular's relating to $\Lambda$ glonomy are published with department funds.) 
Investigations are carricd on, not only in the laboratories and on the farms at Urbana, but also away from the University, as in the detail soil survey (now moke than half completed), which is ultimately to cover every farm in every county, and on more than forty experiment fields well distributed over the entire state on the most extensive and important areas of the various soils of Illinois.

\section{SOIL SURVEY AND FIELD INVESTIGATIONS}

During the last two years, the soil survey has been completed in seven

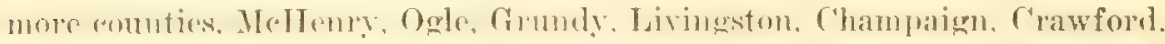
and White; the analytical work on trustworthy samples farly replesenting different kinds or types of soil has male substantial progress; and the funal soil reports hare been published for the counties of Iake, Pike, McIscan. Wimebago, Kankakee, and Tazewell.

These reports include: first, the soil maps showing the type or types of soil on every part of every farm; second, the analytical data giving the deficiency or abundance of the different elements of fertility in every type of soil; and, third, the record of results secured from actual trials on experiment fieds representing the most important soils, demonstrating under mormal field comblitions the value of pormanent systems of soil improvement and maintenance in contrast with the older and more common farm practice, which too commonly tends toward soil depletion.

A few typical illustrations of results secured in these field demonstrations may aid in a fair understunding of their value and influence:

On the Raleigh experiment ficld, in Saline county, the crop values were $\$ 5.52$ form land with no soil (morichnent, $\$ .02$ where the farm manure was applied in proportion to the rops produced. and $\$ 12.30$ where gromul limestone was applied in addition to the farm manure. 'These results represent equal areas of land and the average of four different trials covering five years. The increase from the use of IMMESTONE was practically equal to the total produce from the maided land. For this soil, limestone is the material of first importance, altho it is not the only thing required for the highest implovement.

On a very different kind of soil on the Green $V$ alley experiment field. in Tazewoll eounty, the value of produee was $\$ 12$. 89 from land not enriched. while with the applieation of Notrocise the value berame \$30.35., making an increase of $\$ 17.47$ for the application of nitrogen, an element which seience has shown to exist in the atmosphere in inexhaustible amounts and to be obtainable without purchase by the use of nitrogen-fixing bacteria. These results represent the average of triplicate trials covering six years on the Green Valley experiment field, showing that in this soil nitrogen is the limiting element.

Prices used: 50 cents a lusbel for corn, 40 cents for oats, $\$ 1$ for wheat, and $\$ 10$ a ton for hay. 
On the Manito experiment field, in Mason county, on another kind of soil, the land yielded produce valued at $\$ 6.68$ where no POTAssium was applied, but with this element provided the average value hecame $\$ 20.02$. as an average of triplicate trials over four years.

Neither nitrogen or limestone is needed on the Manito field, and where phosphorus was applied at a cost of $\$ 3.00$, the value of the inerease produced by it was 65 cents on the Manito field and only 5 cents on the field at Green Valley. But, in contrast with these results, on the Bloomington experiment field, the common $\$ 200$ com-belt prairic land of MeLean enunty produced $\$ 18.8+$ with no soil enrichment, $\$ 29.88$ where $\$ 3.00$ worth of PHosPHorus was applied, $\$ 29.83$ with phosphorus and nitrogen, $\$ 30.01$ with phosphorus, nitrogen, and potassium, and $\$ 19.45$ where the nitrogen and potassium were applied without phosphorus. These are the average results from field trials covering fiftecn years, and plainly show that phosphorus is of first importance on this type of soil, which is general in ecntral Illinois.

These markedly different treatments required on different types of soil strongly emphasize both the importance of soil investigations and their great practical value in aceurately finding what is the limiting element. As a ten-year average, corn grown every year on unfertilized land on the University farm at Trbana produced 28.8 bushels per acre, while, with practical, seientifie soil enrichment, corn grow every year in a good rop rotation averaged 79.5 bushels during the same decade.

The fact that all of the domestic animals on the farms of Illinois are equivalent to only one cow for more than 8 acres of our farm land lends additional interest to the rational use of other materials than farm manure for use in permanent, profitable soil improvement.

\section{CROP INVESTIGATIONS}

The improvement of crops in quality and yicld by selection and breeding. the testing of varieties, and of methods of planting and tillage and rare of erops, are likewise under active investigation, and, in these lines as well as in soils, the Department of Agronomy has made important discoveries and established prineiples of fundamental importance to Illinois agriculture: for example, that shallow cultivation of corn is better than deep cultivation; that the great value of cultivation lies not in the conservation of moisture, but in the eradication of weeds, and. consequently. that to cultivate corn more than is necessary to destroy weeds is unprofitable; that the planting of soybeans or cowpeas with the corn or at the time of the last cultivation does not increase, but decreases the vield of com; and that extra deep plowing or subsoiling is detrimental rather than beneficial. 


\section{PUBLICATIONS}

Some of the more recent investigations are reported in the following publications of the Acronomy. Department issued during the last two years:

BULLETINS:

177 Radium as a Fertilizer

179 A Biochemical Study of Nitrogen in Certain Legumes

181 Soil Moisture and Tillage for Corn

182 Potassium from the Soil

183 Prices and Shrinkage of Farm Grains

190 Soil Bacteria and Phosphates

191 Fields of Different Varieties of Corn in Illinois

193 Summary of Illinois Soil Investigations

194 A New Limestone Tester

195 Yields of Spring Grains in Illinois

Circulars:

181 How Not to Treat Illinois Soils

18.5 A Limcstone Tester

1S6 I. The Illinois System of Permanent Fertility from the Standpoint of the Practical Farmer

I1. Pliosphates and Honestry

SOIL REPORTS :

9 Lake County Soils

10 McLean County Soils

11 Pike County Soils

12 Winnebago County Soils

13 Kankakee County Soils

14 Tazerell County Soils

\section{EXPERIMENT FIELDS}

Berause of their confidence in the practical value of the investigations conducted, many loeal communities have donated permanently to the University most of the tracts of land used by the Agronomy Department for rxperiment ficlds, such as the following, aggregating about 600 acres:

\footnotetext{
Aledo field, Mercer county

Carlinville field, Macoupin county

Carthage fielel, Hancock county

Clayton field, Atlams county

Hlizabethtown field, Hardin county

Dixon field, Lee county

Enfield field, White county

Ewing field, Franklin county

Hartsburg ficld, Logan county

Joliet field, Will county

Kewanee field, Henry county

IaMoille field, Bureau county

Lebanon field, St. Clair county
}

\author{
Minonk field, Woodford county \\ Mount Morris ficld, Ogle county \\ Newton field, Jasper county \\ Oblong field, Crawford county \\ Oquawka field, Henderson county \\ Paua field, Christian county \\ Raleigh field, Saline county \\ sidell field, Vermilion county \\ Sparta field, Randolph county \\ Spring Valley field, Bureau county \\ Toledo field, Cumberland county \\ Brookport-Unionville field, Massac county \\ West Salem field, Edwards county
}

\section{NEEDS OF THE DEPARTMENT}

'The Department of Agronomy is greatly in need of additional appropriations in three lines; namely, $\$ 15,000$ a year for increased instruction and to provile for neeled investigation in the subjert of Farm Mechanies: $\$ 10.000$ a year for cxtending the investigations relating to Farm rrops: and a moderate sum to strengthen the faculty.

With these additions to the present funds, the department should be able to render reasonably well the service required by the people of Illinois. 



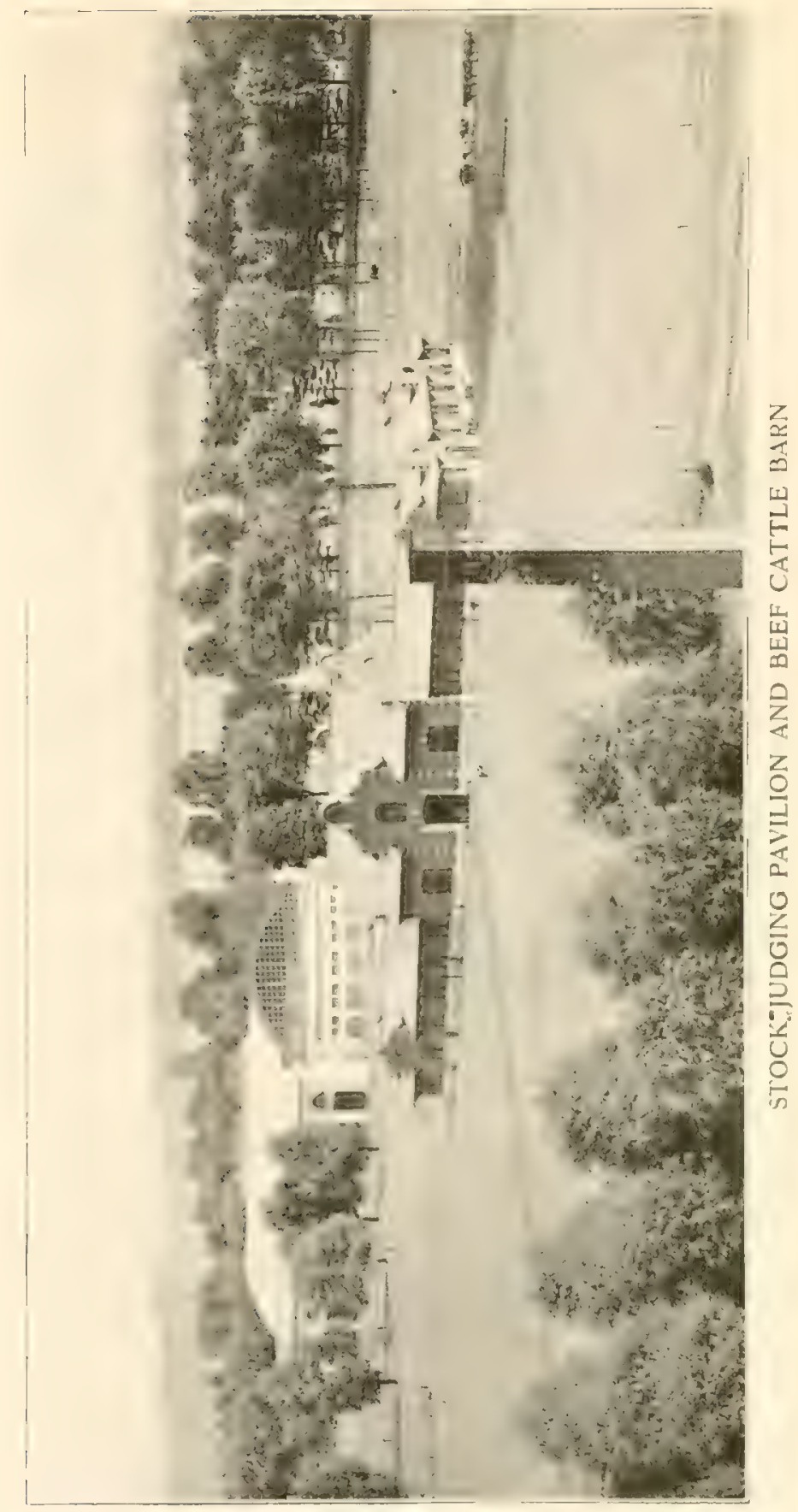




\section{DEPARTMENT OF ANIMAL HUSBANDRY}

Prepared by Herbert W. Mumford, Head of Department

66 FROM the most dependable statisties I have been able to sceure, I find 1 that in the United States, Illinois ranks sceond in the production of horses; fourth in the production of mules; fifth in the production of cattle other than milch cows; fourth in the production of cows; seventh in the production of sheep; and second in the production of swine. Illinois ranks third in the total value of its live stock. On Jannary 1, 1916, the estimated value of live stock in the state of Illinois was $\$ 332,911,000$, being exceded only by the states of Texas and Iowa." 1

The work of the Animal Husbandry Department is directed along three lines : instructional, investigational or experimental, and extension.

\section{INSTRUCTIONAL WORK}

The instruetional work of the Animal IIusbandry Department for the year 1915-1916 included 28 undergratuate and 1.) graduate courses, with a combined enrollment of 2.269. () this number, 28 students were enrolled in graduate courses; 1,400 in judging; and the remainder in meat, breeding, feeding, and production courses.

The purposes of the courses offered are to fimiliarize the student with market and breed types of live stock; the principles underlying the feeding, breeding, and managenent of horses, heef eattle, swine, sheep, and poultry; the judging and selection of animals for breeding and for the feed lot; the methods of marketing; the slaughtering, cutting, handling, and curing of meats; and the chemical and physiological phases of animal untrition. The graduate courses offer opportunities for advanced work in the various phases of animal husbandry. In addition to the regular staff of the department. leading authorities on the various phases of animal husbandry are invited to address the students at times best calculated to give to the student the greatest help.

The instructional work and other academic activities of the department are carried on by 28 individuals. Without attempting to give the distribution as between college, station, and extension work of each individual, it may be stated that on an average, 47.5 percent of the time of the staff is devoted to college, 44 percent to station, and 8.5 percent to extension work. In saying this, it should be understood that some men devote practically their entire time to the College; others to the Experiment Station; and still others to extension work. The general poliey, however, is that, so far as practicable, each member of the staff does some teaching. some station work, and to a much less degree, some cxtension work.

${ }^{1}$ From "The Live Stock Situation in Illinois, "'an address delivered by Herbert W. Iumford to the Illinois State Farmers' Institute, February 23, 1916. 
The instructional work is facilitated by well-equipped laboratories, a stuck Julging Pavilion offering ample opportunity for the handling of large classes in the judging of live stock, and by a well-organized reading room.

The reading room contains about 2,000 volumes, among which are reference books, encyclopedias of animal husbandry, all publications of the f ensus Bureau and of the I'nited States Department of Agriculture, many of the latest books published on the ratrious phases of animal husbandry. and complete files of the Imerican amb British live-stock jommals. In the reading rem an also to be found 60 werkly and monthly live-stock journals and 15 daily live-stork market report papers. A new adjunct to the reading room which has ereatly facilitated pedinge and bresd history work is the herdbook room, into which have been moved the 75 sets of the different herd, stud, and toek registers. To further supplement the herds and flocks of the University, 1,000 or more lantern slides, charts, diagrams, photographs, and models are available for classroom purposes.

The rollowr farm is storked with heleds. flocks, and sturls which contain betwern 800 and 900 head of pure-brod and grade live stock, consisting of the learling breeds of horses, heef aittle, sheep, and swine, together with 2.000 domestie fowls. Experimental attle to the number of 100 to 200 head are frequently a part of the equipment of the department. An effort is made to maintain areditathe sperimsens of the leading breeds of live stock: and the flocks, herds, and studs of the University are rapidly coming to a grade of excellence where they are of interest, not only to the breeders of this state, but also to other states as well.

That the merits of the herds and flocks of the University are recognized by breders of the conntry is indionted by the keen demand for breeding stock. In meent years breeding animals have been sold by the University and shipped into (alifornia. Washington. Ttah, Wyoming, Nevada, Colorado, New Mexiro, Louisiana. Mississippi, Arkansas, Texas, Ohio, Michigan, Pennsylvania, Virginia, New Hampshire, South Carolina, New York, Missouri, Indiana. Iow a, and lientueky, bexides numerous shipments within the state.

The live-stock equipment of the department is necessarily expensive to maintain. "The real purpose of this equipment being to furnish live stock for instructional purposes, it is not possible to manage them primarily from a commereial standpoint. Every effort is made, howerer, consistent with the fundamental purpose of keeping live stock on the Collece farm, namely rdueational, to keep the cost and maintenance down to the minimum and to dispose of distarded and surplus steck to the best advantage possible. In addition to the eost of fording and housing the live stock, there is a large

${ }^{1}$ It is significant that loreeding stock has been sold from the beef cattlo and sheep divisions of the department at higher prices than the University has ever paid for foundation animals in these classes of live stock. 


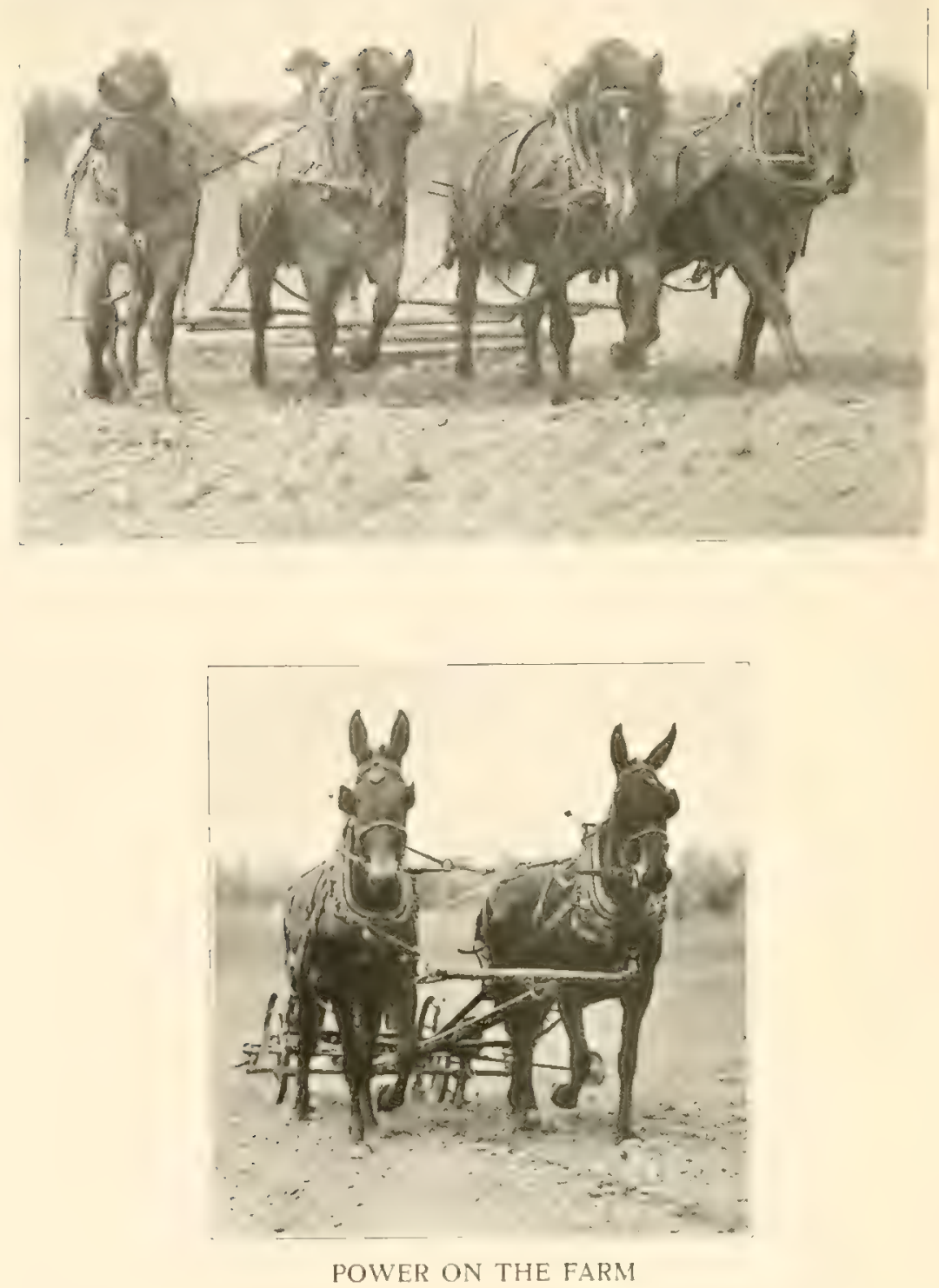
element of labor involved, not only in making it possible to present these animals to the students in the classroom in proper condition, but also in bringing the animals to and taking them from the Stork. Judging Pavilion.

\section{EXPERIMENT STATION WORK}

The attention of the Beef Cattle division has been directed mainly along two lines: first, the continuation of the projects started in December, 1912, to determine the methods anrl cost of raising beef eattle on the highpriced lands of Illinois; and, second, the methods and cost of growing and fattening baby beeves. This division is also cooperating with the Nutrition division of the department in investigating the subject of silage and forage poisoning of live stock.

The Sheep division has been working on the different methods of raising and fattening lambs for the market. These investigations have involved the subject of the place of silage in the maintenance of the breeding flock and in fattening rations for sheep and lambs.

The Swine division is carrying on work to determine the cost of maintaining brood sows; the relative efficiency of light and heavy feeding; the amount of pork produced per bushel of corn consumed when pigs are allowed to gather the corn from the field as comprared with methods of feeding which are commonly used; and the relative value of different forage crops in supplementing the grain ration for fattening hogs. The question of the use of the self-feeder is also under investigation.

The Horse Husbandry division has directed its attention to investigating the methods and cost of growing draft mares to two-year-olds, and the relative efficieney and cost of maintaining draft horses and mules for farm labor. Both of these projects are still in progress.

The division of Geneties has directed its attention along two lines: determining the independence or coupling in unit characters in the inheritance of manmals, and determining the mode of transmission of cloven and mule-foot condition in swine.

The investigational work of the Nutrition division has been centered npon two projects; the first consisting of a series of digestion experiments with pigs; and the second, an experiment to determine the nutritive value of the proteins of feeding stuffs.

The Farm Organization and Management division is conducting cost accounting investigations to determine the cost of producing crops and live stock as found under representative types of Illinois agriculture, and to study the relation of the various enterprises to the farm business as a whole. Particular attention is given to the study of the economic production of eattle and hogs, and to horse labor as a factor in the cost of produeing farm crops. 


\section{PUBLICATIONS}

The principal publications issued by the Animal Husbandry Department include the bulletins, which summarize the experimental work, and the circular's of information, which deal with experimental and general live-stock topies. Approximately 2,500,000 ropies of these bulletins and circulars have been issued. That the reader may form a better iclea of the nature and scope of the experiment station work of this department, the list of bulletins and circular's which it has issued are enumerated below.

\section{BüLLETINS:}

73 Comparison of Silage and Shock Corn for Wintering Calves Intended for Beef Production

78 Market Classes and Grades of Cattle with Suggestions for Interpreting Market Quotations

83 Feeds Supplementary to Corn for Fattening Steers

90 Fattening Steers of the Various Market Grades

$9 \overrightarrow{7}$ Market Classes and Grades of Swine

109 The Location, Construction, and Operation of Hog Houses

110 Storage Barns, Sheds, Feed Lots, and Other Equipment for Feeding Experimental Cattle in Car Load Lots

111 Maintenance Rations for Beef Breeling Cows

122 Market Classes and Grades of Horses and Mules

129 Market Classes and Grades of Sheep

141 Relative Efficiency of Difierent Rations for Fleshing Horses for Market

142 Short Fed Steers. A Comparison of Methods of Feeding

147 Market Classes and Grades of Meat

149 Tuberculosis of Farm Animals

150 Feeding Farm Work Horses

152 Contagions Abortion of Cows

158 Nutritive Value of the Varions Cuts of Beef

163 The Maintenance Requirement of Swine

165 The Element of Uncertainty in the Interpretation of Feeding Experiments

166 Review of American Inrestigations on Fattening Lambs

167 Proportions of Sbelled Corn and Alfalfa Hay for Fattening Western Lambs

168 A Study of the Development of Growing Pigs

169 A Study of the Ash Content of Growing Pigs

170 Coefficient of Digestibility of Some Common Rations for Swine

171 A Study of the Phosphorous Content of Growing Pigs

172 A Study of the Digestiluility of Rations for Steers

173 A Study of the Forms of Nitrogen in Growing Pigs

192 Feeding Pure-Bred Draft Fillies

\section{Circulars:}

48 The Characteristies of Stockers and Feeders

61 Supplement to Bulletin 73, Comparison of Silage and Shock Corn for Wintering Calves Intended for Beef Productions

65 Live Stock Inrestigations

79 Present Methods of Becf Production, I (Introduction)

83 The Srine Industry from the Market Standpoint

88 Present Methods of Beef Production, II (Fattening Cattle) 
91 Present Methods of Beef Production, III (Hogs Following Cattle in the Feed Lot)

92 Present Methods of Beef Production, IV (Feeds and Their Preparation)

94 Present Methods of Beef Production, V (Breeding Beef Cattle for Market)

98 Present Methods of Bcef Production, VI (Feed Lots and Shelter)

104 Detailed Bill of Material for Storage Barns, Sheds, Feed Lots, and Other Equipment for Feeding Experimental Cattle in Car Load Lots

125 The Sheep Industry from the Market Standpoint

126 Food Requirements for Growing and Fattening Swine

132 A Portable Panel Fence

133 Feeding the Pig

140 The Live Stock Situation in Illinois

153 Facts in Swine Feeding; Special Reference to Developing Swine for Breeding Purposes

161 Growing and Marketing Wool

163 Relation of the United States to the World's Beef Supply

164 Argentina as a Factor in International Beef Trade

169 A Review of Beef Production in the United States

175 Cattle Feeding Conditions in the Corn Belt

178 The Foot and Month Disease Situation

The bulletins on the Market Classes and Grades of Cattle, Horses, Swine, Sheep, and Meat are the only series of the kind ever prepared and are a valuable contribution to animal husbandry literature. At the time of the St. Louis World's Fair, 1904, the management considered the bulletin on Market Classes and Grades of Cattle (No. 78) of such great importance that the Department of Animal Husbandry was asked to prepare an exhibit which would represent the grades illustrated and deseribed in this bulletin. This exhibit was prepared and pronounecd the most valuable from an educational point of view of any live-stock exhibit in the entire show. 1 similar exhibit was made at the International Live Stock Exhibition the same year and has been similarly commended since that time. This material has often been used at our State Fair and at various exhibitions in this and other states, including the Panama Pacific International Exposition at San Francisco in 1915. The information it convers becones more significant each year.

Publications are in preparation by members of the department on such subjects as the relative cost of maintaining horses and mules for farm labor ; the influence of one feeding stuff upon the digestibility of another; the individuality of pigs as to the completeness with which they digest their food.

\section{BUILDINGS}

With the exception of the brick Beef Cattle Building, ereeted 19011905, the college and station live stock are housed in frame buildings of a more or less temporary nature.

The Geneties Building (erected 1915-1916) is a one-story brick structure, 42 by 140 feet, containing the laboratories, offices, and animal rooms 
of the Genetics division of the Animal Husbandry Department. The building is used for teaching purposes and for the investigation of the transmission of characters in animals and plants with particular reference to domestic animals.

The stock Iudging Parilion (erected 1913) is a fireproof building, 54 feet high on the front and 148 feet deep, with circular ends 92 feet in diameter and 20 feet high. The exterior is brick and terra cotta, renaissance in design, the fricze being enriched with medallions of animal heads, representine modern breed types of the various elasses of live stock. The total ground area is 30,000 square feet; the show arena is 220 feet long and 65 feet wide with a seating alpacity of 2,000 . Four elasses of 40 students "aleh can be held in the arena at the same time. The building also contains classrooms and offices. There are approximately 1,400 enrollments in regular classes using this building during the school year.

The Cattle Feeding Plant, now under construction, will be 374 feet long when completed. The main part of the plant is to be 52 feet wide and over in feet high, having a storate capaleity of to0 tons of hay, 13,000 bushels of small grain, and 7,000 bushels of ear corn. In addition to the main plant there will be a battery of 4 silos, each 16 by 70 fret, with a total eapacity of over 1,000 tous. Two of these have already been built. The plant will be exuipped with machinery for the efforent handling and preparation of ferds. The fecling lots, which are to extend out 30 feet from the building line. will be pared. The maximum capacity of the plant will be 200 head of mature cattle.

The equipment for investuational work in Animal Husbandry consists of laboratories for analysis of fercling materials and excreta, and for research work in the more advanced chemical and physiological phases of animal nutrition: breeling laboratories for rxperimentation on mice, rats, rabbits, guinea pigs, and other suitable mammals: cold storage rooms and other equipment for conducting tests in cutting and handling meats; frame buildings for the housing of the vallous kinds of live stock, with the appliances necessary for individual and collective feeding tests, paved and unpaved feeding lots; and opren sheds for experimentation with horses, eattle, sheep, and swine.

\section{EXTENSION WORK}

A summary of the work of the Animal II susbandry Department should not fail to include that part which is offered directly to the people.

During the past year the extension artivities of the department reached into $4 t$ countics of the state. Lectures were delivered at farmers' institutes, extension sehouls, farm managument associations, county adviser's' meetings, live-stork and brecders' association meetings, the Boys' State Fair School, teachers' and parrnts" meetings in schools, rounty fair schools. and corn 
shows. Fifteen of the members of the department delivered extension lectures, thru which 15,222 people were reached.

\section{NEEDS OF THE DEPARTMENT}

Beef Cattle Division. The completion of the beef cattle feeding and storage plant is urgently needed. It is designed to make the latter a central storage plant for all classes of live stock, and until this is secured we shall not be able to purchase feeds as cconomically as can be done with suitable storage facilities.

Meat Division. A laboratory for slaughtering, ripening, curing, and cutting meat is needed. This lahoratory should be of sufficient size to take care of students registered in the meat courses, and, manifestly. some of their activities in handling meat would include more than is indicated above. The enrollment in the meat courses at the present time is about 40 , but a special effort has been marle to keep this enrollment down to a small number as the division is not in a position to handlo la race numbers. This laboratory should be equipped for conducting experiment station work as a supplement to our present live-stock production investigations.

Horse Division. One of the rhief limitations to the development of our courses in howe hushandry is a lack of arailable high-class horses. If the stabling in comnection with the Stock Judging Pavilion, as originally planned, could be provided, it would make it possible for us to secure material additions to our equipment by loans from breeders and exhibitors who will not run the risk of sending their stock here now in the absence of sanitary stabling.

Swine Division. With the purchase of the Lindsey farn and the location of the new beef eattle feeding and storage plant in elose proximity to the old swine hushandry location, it is contemplated to move the swine to a portion of the Lindsey farm. This will make it necessary to rebuild the swine plant. Fortumately, no expensive buildings have been erected at the old plant, but provision should br made, within the next two years, for the ercetion of suitable buildines to quarter this division of our department.

Cottages for Herdsmen and Shepherd. With the growth of the University and the neressity for moving our live stock farther away from the campus, it becomes increasingly necessary to provide cottages in which the herdsmen and shepherd ean live in close proximity to their work. The policy of providing eottages for such men has long been under consideration, and efforts have been made properly to eare for the work by other methods, but the departmental staff have come to the conclusion that this is the most satisfactory and the only safe method of earing for our live-stork equipment. At present theie should be provision made for erecting a cottage for the beef cattle herdsman, another for the swine herdsman, and a third for the shepherd who looks after the University flock. 
Animal Pathology. Students specializing in Animal Husbandry are handicapped at present thru a lark of opportunity to take work in animal pathology or veterinary science. It is true, too, that some of the investigations, particularly the one in forage poisoning, are being hampered by the lack of a competent animal pathologist who has been trainced for such work.

Animal Nutrition Division. For both the research and instructional work, the Nutrition division needs a larger laboratory for the experiments with animals, a laboratory which would include 12 feeding stalls for pigs and sheep similar to the four new stalls in the Beef Cattle Building for cattle and horses. In this same commetion about three times as much space as we now have in the Beef Cattle Building is needed for the sampling of feeds, for the storing of feeds, and for the weighing of feeds and excretory products. The Nutrition division needs a bomb ealorimeter for the purpose of computing the heat of rombustion of the feeding stuffs that are being used in the nutrition experiments and also for the purpose of analyzing the feculine stufts which other members of this department are using in connection with their work.

Poultry Division. The Poultry division needs strengthening. The work is now advanced to a point where the major part of the time of one man is required to care for the extension calls. There should be one or possibly two new men added to this division as soon as practicable. The University of Illinois is doine less in poultry hushandry than possibly any college or experiment station of goml standine in the Tnited States, and even than less important stations. 'Thus far, only temporary, inexpensire buildings have been ereeted for housing the poultry. The building equipment is entirely inadequate properly to care for present activities, to say nothing of any derelopment of the work. It will be necessary in the very near future to erect more and better structures for this purpose.

Land. The land devoted to farming and experimental purposes under the supervision of the department now comprizes 355 acres, 80 of which are rented. If the department were provided with sufficient land to grow all of the feed necessary fully to maintain its live-stock equipment, from 600 to 700 acres would be required. It is necessary that sufficient corm be grown to fill the silos and provide sufficient pasturage for the live-stock equipment. It is felt that the prescut acreage of 35.5 acres, 80 of which, it should be borne in mind, are rented, is the minimum amount of land with which this can suceessfully be done. To be assured that land will be avalable as needed, the University should acquire either the 80 acres now rented by the department or its equivalent elsewhere. This, as has been said, would be a minimum; it would he adrisable to have available for the use of the department at least 400 acres. 



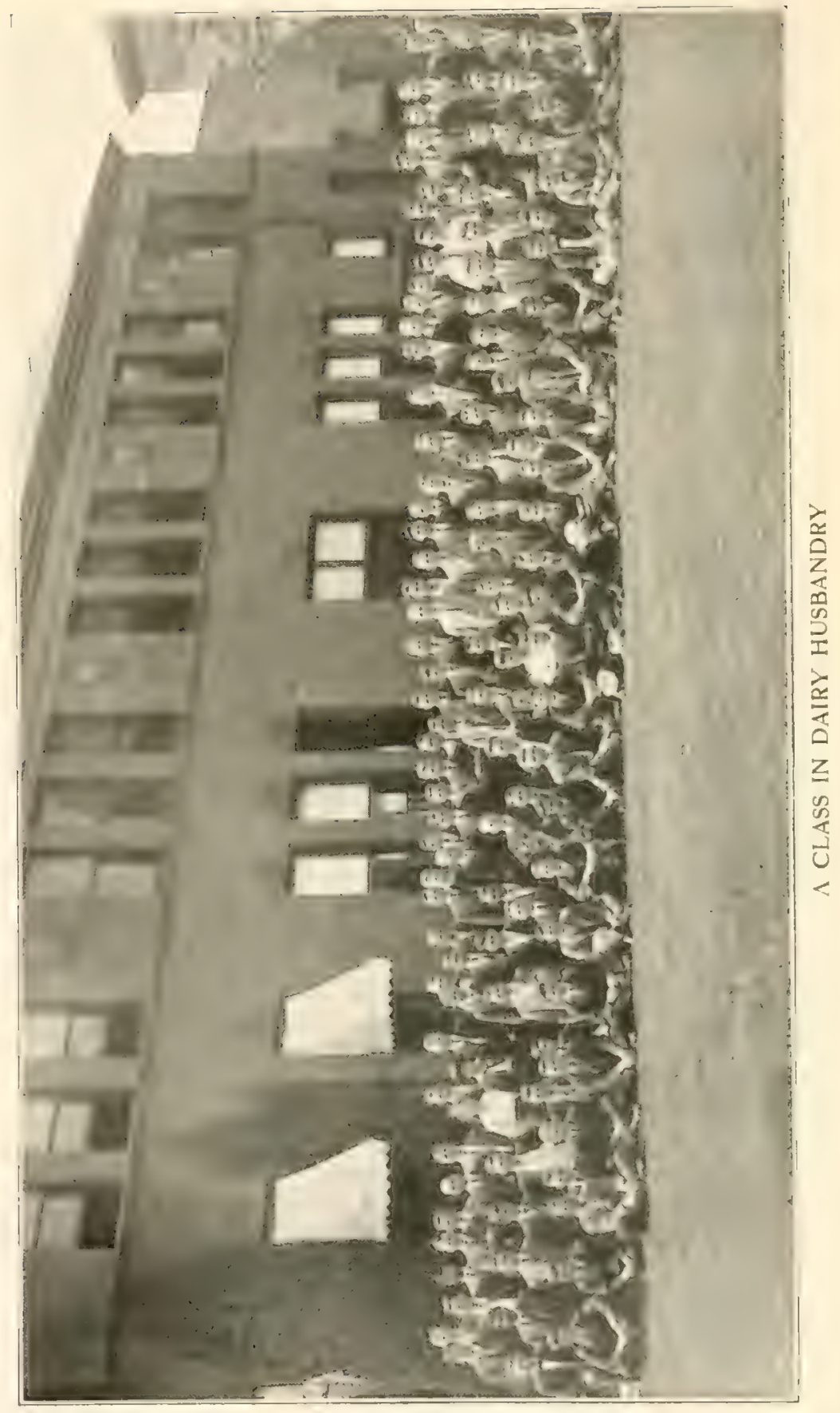




\section{DEPARTMENT OF DAIRY HUSBANDRY}

Prepared by H. A. Harding, Head of the Department

$\mathrm{T}^{\mathrm{u}}$

HE steadily increasing cost of human food is producing a shift toward dairying in the agriculture of the state. This in turn is bringing increasing demands upon the Department of Dairy Husbandry.

\section{COURSES OF INSTRUCTION}

The teaching problem of the Dairy Department is to train students along the lines of the production, manufarture, and marketing of milk and its products. In doing this it offers 21 different courses of instruction. which, during the present year hare had a total enrollment of slightly orer 700 four-year students.

Notwithstanding this evident interest in the subject, as shown by the large number of students cnrolled in the dairy classes, the teaching of the subject is in several respects not as well developed here as it is at the Agricultural Colleges of Wisconsin and Iowa, our neighboring institutions in states where dairying has essentially the same importance as in Illinois. Our present limitations as to men, equipment, and buildings will be discussed under the heading of department needs.

\section{EXPERIMENT STATION WORK}

The inevitable high cost of all food is constantly raising questions as to various methods by which the cost of production of dairy products may be reduced. The following studies are being made of various aspects of this cost question.

The question of ealves and ealf raising has been stimulated by the inrreasing price of dairy cows and the increasing need of cows that shall be economical producers of milk. From careful studies of the growth and development of 125 calves, fed upon various combinations of the ordinary farm feeds and manufactured feeds, it has been concluded that while hay and various cereals and their products may early become an important part of the food of the calf, satisfactory development does not appear possible without the liberal use of whole or skimmed milk during the first two or three months of its life.

Closely connected with ealf raising is the question of the influence which the feeding and development of the calf and heifer up to the time of freshening may exert upon the milk production of the resulting cow. Manifestly this is difficult to measure because of the large influence of breeding upon milk flow and the difficulty of getting a sufficient number of experimental calves of the same or like brecding, but investigations are under way looking to a solution of the problem. So far as the experiment has gone the variations in feeding before freshening have resulted in distinct differences in the size of the cows and their ability to produce milk. 
Labor is an inceasingly important factor in milk production and has led 10 much consideration of the milking machine. Studies of the effect of the machine upon the lacelation period of cows and heifers, upon the amount of milk profuced, and upon the relative cost of marhine milling and hand milking have been in propress for smme time. The conclusions which appear evident at the present time are that when properly handled the milking machine has no objertionable results upon the cow and in large herds it is ecomomical from the stand point of labor. As they are ordinarily handled, however, milking machines increase the germ life of milk and have an undesirable effect upon the keeping quality of the milk.

An investigation is being made of the causes that influence the germ rontent of nilk. The wholesile price of milk produced in Illinois each year" for the city trade amounts to about $\$ 30,000,000$. Because of the relation of the milk business to the public health, many municipalities have for-

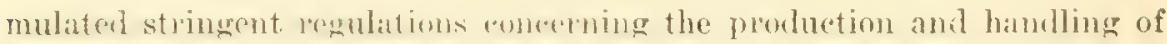
milk. While these regulations have been mare in good faith, they freguently require the producer or the hamller to go to considerable expense in matters about which there is no exact information as to their importance.

The studies undertaken have already emphasized the fact that too much stress has been latil upou the matters of barn eonstruction and general appearances, which hav really very little effect upon the quality of the milk. On the other hand, they have served to emphasize the overshadowing importance of the condition of the pails, strainers, and eans with which the mill: comes in actual eontaret. Even when these are elean, in the ordinary meaning of that word, they are frequently so highly populated with germ life that the milk is promptly started on the road to souring. Studies are now under way to defermine the most pratiral methods of handling the utensils in order to have them in satisfactory condition for handling milk.

As the result of these studies it is hoped that the cities of the state will remove those restrictions upon the milk business which increase the rost of production withont serving any useful purpose. It the sime time the dairymen should be mabled to produce a better milk at a smaller cost.

The above studies aim at reductions in the cost of the milk production hy making possible improvements at individual points. At the same time a more acenrate knowledge of the total cost of milk production, as well as knowledge of the romparative importance of the various factors that turether make up this total cost, is of considerable importanee. In order to sceure accurate information, since exact data were not available, two lines of study have been carried out:

(1) A survey has been made of the conditions on 725. dairy farms in northern Illinois. C'areful study of the data shows that the question of rosts is very complex and that the actual eost of production varies, not mly with the individual cow, but also with the individual farm in each "ommunity and with the type of dairying in which the community is 



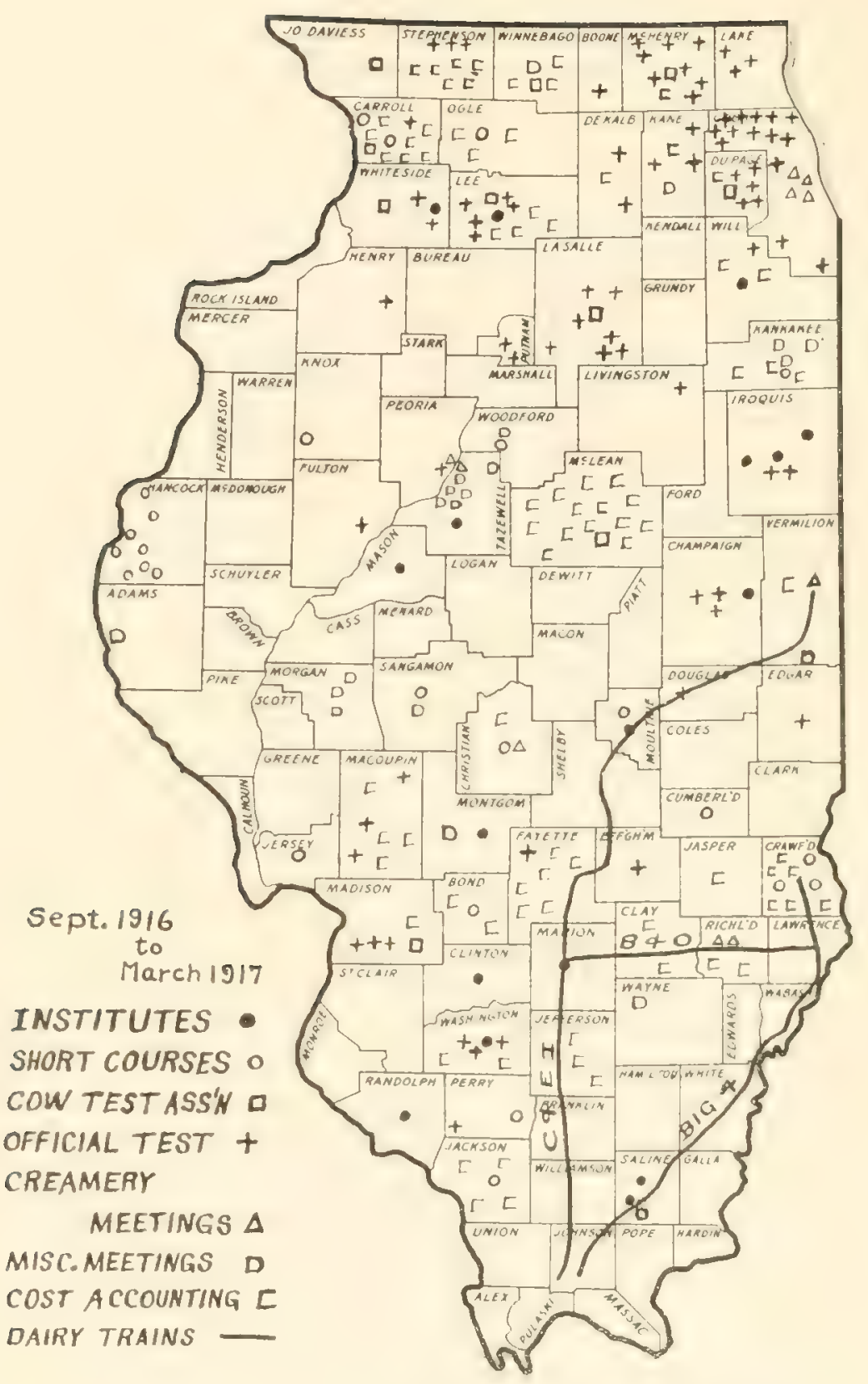

EXTENSION ACTIVITIES OF THE DAIRY DEPARTMENT 
engaged. (2) A complete system of farm accounts has been rarried out with a considerable number of dairymen in different parts of the state. This kind of data has atecumulated thru four seasons and forms a valuable check upon the conclusions which seem to follow from the survey.

The above are given as examples only of the kind of service rendered by the department.

\section{EXTENSION WORK}

At present, in the Department of Dairy Husbandry, extension work occupies the full time of two men and a considerable portion of the time of six others. With this allotment of men satisfactory attention cannot be given to this work, for which there is a large and growing demand.

For a number of years the department has cooperated with the officials of the various dairy breed associations in conducting official tests of milk production in pure-bred dairy herds within the state. These tests are of two general types-short-time tests and tests extending over an entire year. During the year ending December 31, 1916, the department conducted short-time tests on 426 cows in 61 different herds, and yearly tests on 224 cows in 37 different herds. These tests included representatives of six different dairy breeds.

Just before the outbreak of foot-and-mouth disease there was manifest a growing interest in cow-testing associations in this state. With the disappearance of the discase the interest has again appeared. Since June 1, 1916, seren new associations have been formed and are now in working order, and a number more will undoubtedly be formed as rapidly as satisfactory men can be found to act as testers. Where these associations are provided with the right man as a tester, they are of great good in increasing the quality of the herds of a community.

The wave of interest in dairying which is now sweeping over this state has led to considerable attention to calf raising and calf chus. Where these clubs secure desirable ealves at reasonable prices and have good instructions regarding the development of calves into dairy cows, they will undoubtedly be of benefit to individuals and to the dairy industry. Reeognizing the newness and complexity of the calf club situation, the extension forces of the College of $\mathrm{Agrieulture}$ hare entered into cooperative relations with the State Dairymen's Association in the carrying on of this work.

It is a matter of common kuowledge and regret that only about 15 percent of the creamery butter made in the United States is of first quality. The reason for this lies in the poor condition of the eream at the time it is received by the creamery. The problem of the improvement of eream has for some time interested the Illinois Butter-manufactures's Improvement Association. Evidently the method of improvement lies in paring a highel price for the sweeter eream based on some method of grading. In order to assist in working out this crean-grating plan, an extension man has been delegated to work with the creamery men on the problem. 
In view of the growing interest in dairying in souther'n Illinois and the desirability of coming into touch with a wide extent of territory, the department, in cooperation with the railroads and in one instance with the state Dairyncn's $\Lambda$ ssociation, assisted on dairy trains during this winter thru the region from Danville to Cairo and from Lawrenecville to Salem, in this way presenting dairy facts to approximately 25,000 people.

In addition to extension work along these definite lines, the department is represented at farmers' meetings of all kinds and in consultation with various groups in connection with agricultural problems.

The general distribution of the extension activities are shown by the map opposite the preceding page.

\section{NEEDS OF THE DEPARTMENT}

The needs of the Dairy I) Dartment may be briefly cnumerated under the headings of Space, Men, and Equipment.

Space. The specimens of the various dairy breeds in use for teaching purposes are now housed in the original Agrieultural ('ollege barn. This building has pravtically outlived its usefuluess and must soon be rebuilt. I new building ambining the purposes of a barn, with silos and other neessary cquipment, and a laboratory adapted for both teaching and investigation, would probably cost about $\$ 20,000$.

Nowhere is space more needed than in the creamery. Four years agn the space allotted to it was believed to be fully oreupied. Since then the machinery used in the instruction of ice-eream maling and city-milk handling has been installed. The result is that while there is something illustrative of practically every side of dairy manufactures, there is not space enough to treat any side fairly.

The retail eity milk business in this state amounts to over $\$ .70 .000 .000$ per year. while the machinery illustrative of it is erowled into a spare ?0 feet square. The icc cream business, while less in amount, is important and growing rapidly, but its space allotment is necessarily quite as meager.

Laboratory space for proper teaching in connection with city milk problems is simply not to be had. A laboratory for dairy physies is needed quite as much as one for dairy chemistry, for the entire group of processes included in dairy manufactures is applied physics; but again space is lacking.

Men. As the department is now equipped, it is about four men short. If sufficient laboratory spice could be provided to accommodate the students who desire to take work in courses now offered, the shortage of men would be considerably increased.

Equipment. The equipment that has been provided is of good quality gucl on the whole as abundant as the space relations make desirable. However, as soon as adequate space is made available, equipment should be provided. and in the development of the suggested new laboratories new cquipment will of course be needed. 



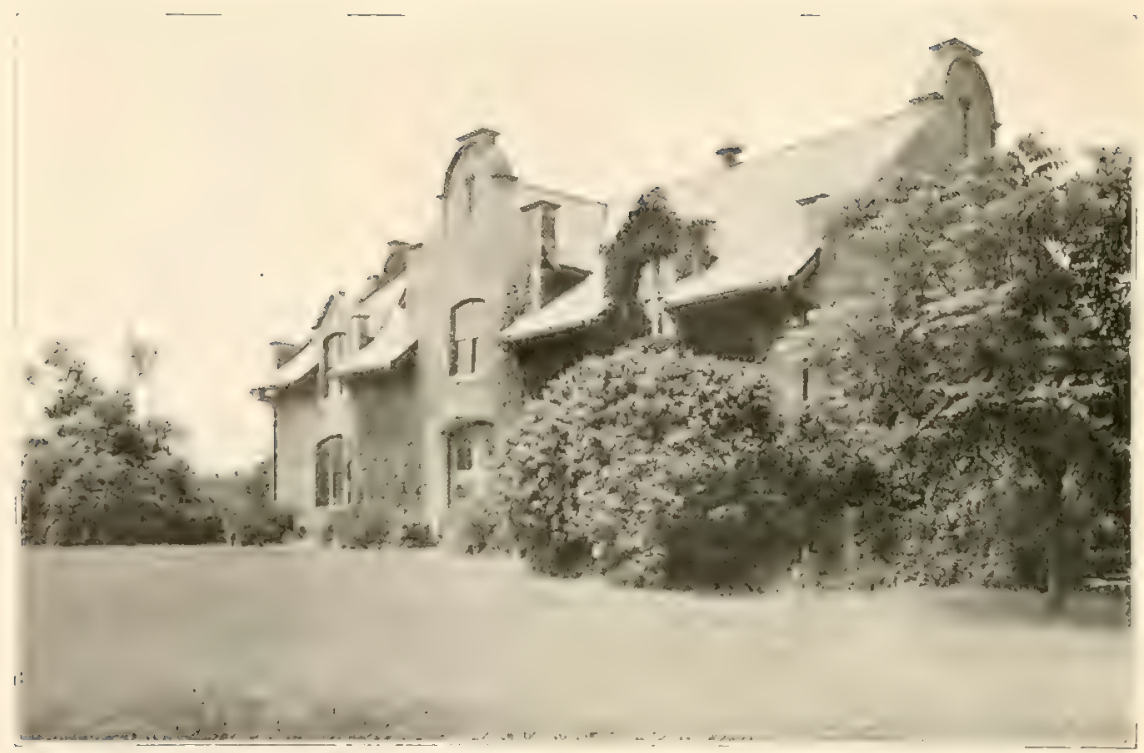

OLD HORTICULTURAL BUILDING, NOW USED FOR MILITARY PURPOSES

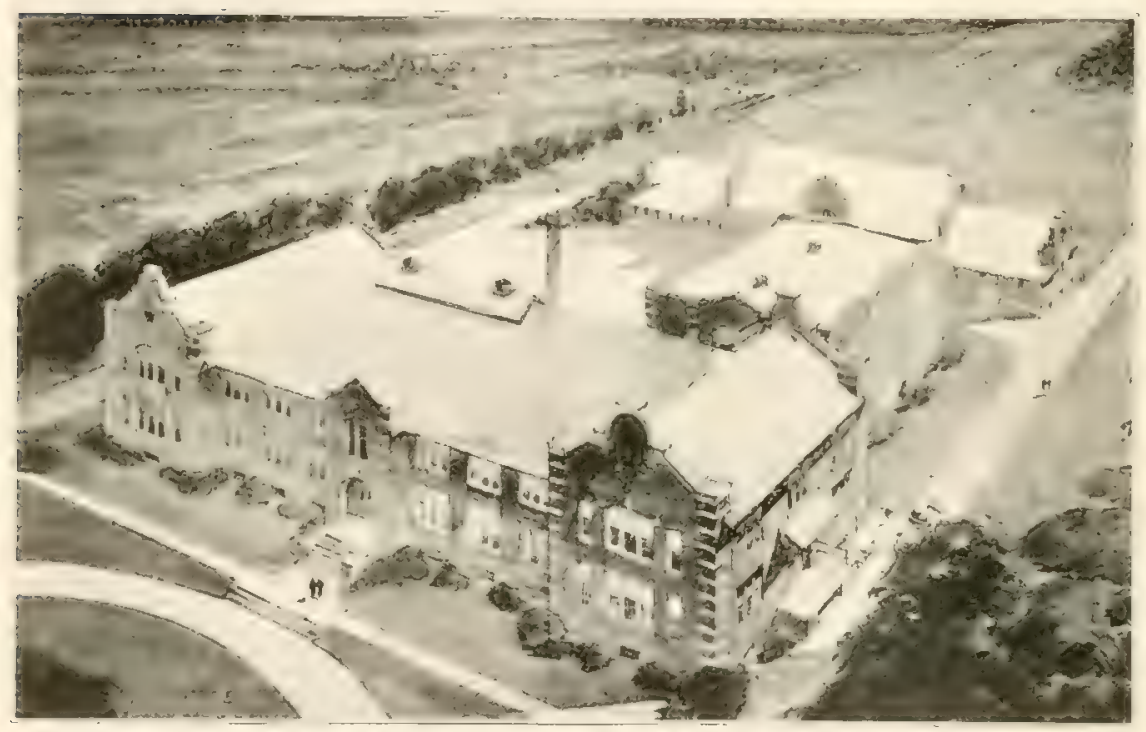

PROPOSED NEW HORTICULTURAL GROUP 


\title{
DEPARTMENT OF HORTICULTURE
}

\author{
Prepared by J. C. Blair, Head of the Department
}

$\mathrm{T}$ HE work of the Department of Horticulture is carried on in five divisions: Pomology, or fruit growing; Olericulture, or vegetable gardening; Floriculture; Landseape Gardening; and Plant Breeding.

Twenty-three members of the staff are engaged in instructional work, which is given in all these divisions except plant breeding. Most of them also devote a part of their time to research work in the Experiment Station.

\section{INSTRUCTION}

During the present year (1916-17) there are a total of 1,615 registrations in the 55 different courses offered by the department. The courses and enrollments are distributed as follows: gencral horticulture, 2 courses, 562 students; pomology, 11 courses, 134 students; olericulture, 3 courses, 21 students: floriculture. 12 courses. 197 students; and landscape wardening, 27 courses, 701 students.

Instruction in general hortieulture is given for the most part by member's of the division of Pomology. An elementary course in general horticulture is required of all freshmen in the general course in agriculture, consequently there is a largo registration in this work each year.

The registration in the division of Landscape Gardening, 701 for the past year, places this school first in the country in point of attendance. The first professorship in civic design in the United States was established in 1914 in ennection with the work in this division.

In addition to the regular hortienltural courses this department offers two professional courses, one in floriculture and one in landseape gardening, both leading to the degree of bachelor of science. Twenty-two students are registered in the professional course in floriculture, and 65 in the professional course in landscape gardening.

Graduate Instruction. Four of the fifty-five courses of instruetion offered by the department are graduite courses, and cover special problems in three of the divisions. Seven gladuate students are registered in pomology, 3 in olcriculture, and 6 in floriculture. It is planned to extend the graduate instruction to other divisions of the department, and to inerease the number of courses and of instructors in subjects already given.

\section{EQUIPMENT}

For the most part, and exeept in landseape gardening, the same equipment is used for instructional and for investigational work. The area devoted to these operations consists of 320 acres in the vicinity of Urbana : in addition, various fruit and vegetable plantations are maintained by the department in sonthern Illinois for spraving and soil experiments in pomology, and for plant selection and fertilizer experiments in olericulture. 
Two buildings are deroted exelusively to horticultural activities. The Floriculture greenhouses (erected 1912-13) consist of ten glass houses with an aggregate area of 28,000 square feet. The service building used in connection with the greenhouses is a two-story structure containing laboratories, offices, classlooms, and potting and storage rooms. Six of the glass houses are used for instruetion, and the other four for investigational work. The houses contain plants representing all forms used in commercial and decorative work. The Vegetable and Plant Brecding grcenhouses (erected 1912-13) consist of three glass houses, - one used for vegetable growing (105 $\times 28$ feet) and two for plant brecling (each $80 \times 30$ feet); a wire house $80 \times 30$ feet; and a two-story service building.

The landscape gardening classrooms and offices are in the $\Lambda$ grieultural Buildine. Four drafting rouns, containiug in all one hundred desks. modern filing devices for office practice, and a very complete library are at the disposal of the students. The library contains an unusual collection of early works on landseape gardening, a collection which was begun with the opening of the University in 1868; it has been kept up to date in both American and forcign publications relating to landseape gardening and allied subjects. A series of two thousand lantem slides is used to illustrate lectures and laboratory work. There is also a collection of representative drawings and blue-prints by practicing landscape arehitects.

\section{EXPERIMENTAL WORK}

POMOLOGY

In P'omology, ol fruit growing, the investigational work consists largely of soil-treatment and spraying experiments for apple orchards of central and southem Illinois. The soil-treatment experiments neressarily eover a considerable period of years. A new experiment with nitrate of soda is planned for the coming season.

During 1916-17 the spraying experiments for bloteh demonstrated the superiority of Bordeaux to lime sulfur, but indicated that Bordeaux applied in sufforient amounts to conten bloteh resulted in bally russeted fruit. It was found that the most important sprarings for bloteh were those applied three, five, and seven wecks after the fall of the bloom.

Results from the test of the dust sprays, in which powdered arsenate of lead and finely divided sulfur were used, indicate in general a rather favorable control of codling moth and curculio, with an unsatisfactory control of apple seab and blotch.

Investigations with regard to spraying peaches and to the control of pear blight are now in plogress.

\section{OLERICULTURE}

In Olericulture, or vegetable gardening, experiments are being carried on with a view to studying inheritance in lettree and to sceuring a better 



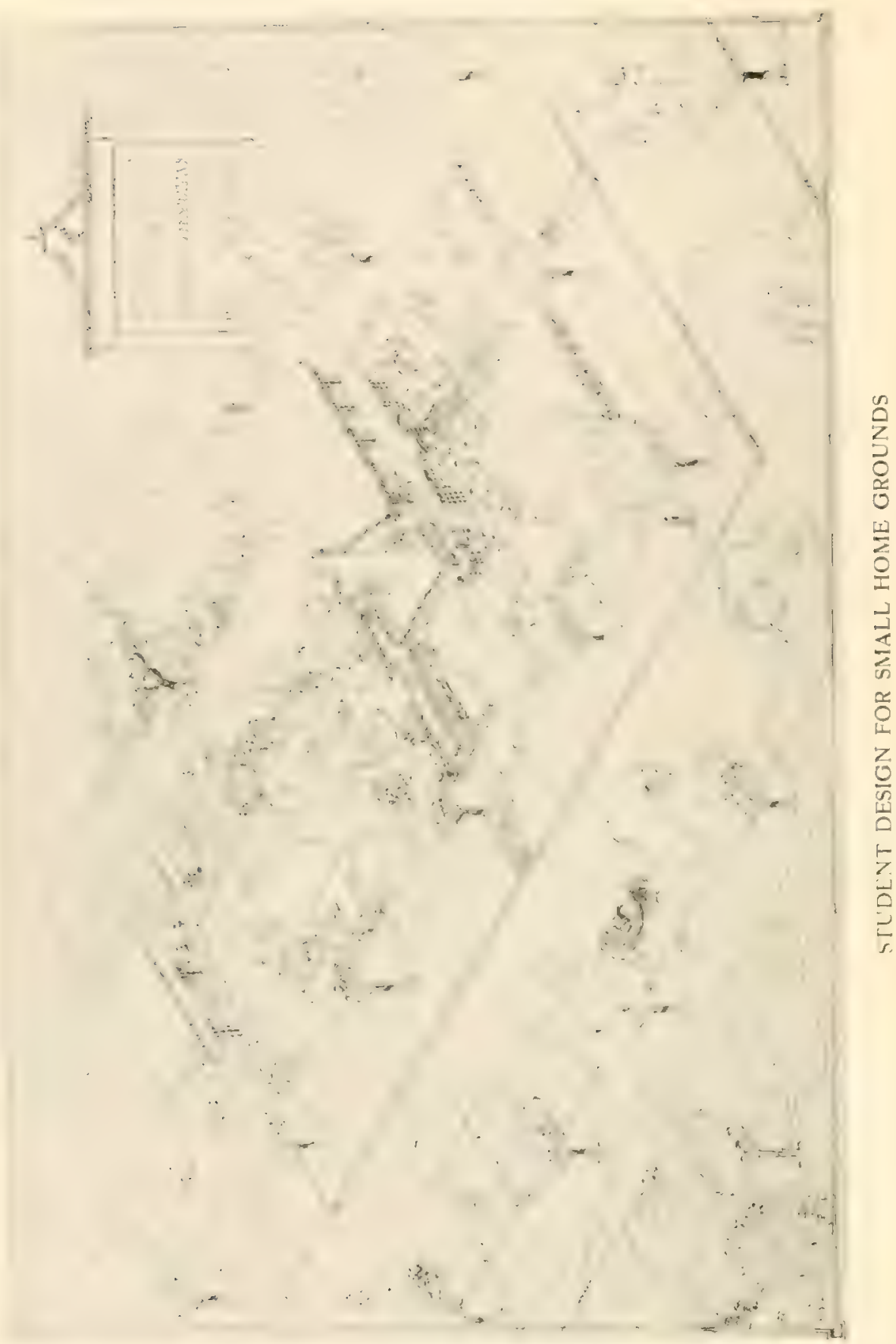


foreing variety of head lettuce. A number of commercial varieties of tomatoes are being tested to determine their yelative resistanee to fusarium wilt. Experiments in sweet potato selection are being conducted for the purpose of isolating types of sweet potatoes found in the ordinary seed and of developing by selection, if possible, improved strains of sweet potatoes.

A fertilizer experiment with tomatos, sweet potatoes, and muskmelons has been inangurated for the purpose of determining the fertilizer needs of these crops in a three-year rotation.

\section{FLORICULTURE}

In Floriculture, fertilizer experiments show that acid phosphate in(reases the production of earnations, and has the same effect with roses of every variety tested, except Hoosier Beauty.

One of the chicf investigations during the present year is the study of the effect of fertilizers on the formation of earbohydrates in plants: it has been necessary to derote considerable time to a preliminary study of methods of carbohydrate analysis in order to secure a basis for leliable and significant results.

Three projects of general horticultural interest have been started in this division: (1) the chemical changes taking place in the ripening of fruits: (2) the earbon-dioxid content of the greenhouse atmosphere; and (3) the chemical changes resulting in apples from attacks by Penicillium.

The work in pathology is directed along thrce lines: (1) giving information as to disease and treatment in eases of trouble in commereial greenhouses; (2) the diannosis of diseases for other divisions and departments upon a request for such information: and (3) the experimental investigation of those diseases which at present are resulting in the most serious loss to the grower, more especially carnation "yellows," the fusarium wilt of carnations, snapdragon lust, and aster "yellows." With all of these the aim is to give an ample and casily recognized description of the disease, the method of transmission, the effect on the strueture and tissues of the plant, and cither to develop a remedy or devise methods of preventing the occurrence of the disease.

A survey of the fungous flora of greenhouse soils is also in progress.

New discases of florieultural plants which have recently eome to attention are a bacterial decay of eyclamens, a crown hlight of Ligustrum vulgare, and a destructive disease of eama rootstock. New or noteworthy diseases other than florieultural that have been met are as follows: a Phoma eanker (if apple, new to the state, if not to the I'nited States: the bacterial shot hole of peach and plum, eaused by Bacterium pruni, not previously reported from this state; a Cytospora blight of plum, peach, and apple showing interesting inter-host relations: a disease seemingly caused by Calosphreria princeps which results in the death of cherry and plum trees; the blight of 
sweet corn cansed by Psendomonas stewarti, previously uneported for the state; a new bacterial chlorosis of field corn; and a leaf blight of the cowpea.

\section{PLANT BREEDING}

Plant-breeding projects originally outlined in 1907 are being condueted.

The studies in apple-bud selection have shown, in a positive way, that so far as growth is concerned, there is no difference in value, for purposes of propatation, between large huds and small buds, or between buds differently situated either on the tree or the shoot.

Ilybridizing between standard varieties of apples and other species of the genus Malus, rrossing between orchard varieties, crossing between strains of the same variety and cren between different individuals of the same strain are all being tried in older to determine the effect of pollination. Studies are in progress with recard to the transmission of eharacters such as size, type of foliage, flower color, flower form, color of seed, and shape of the pollen, sweet peas being used for the purpose because they are well adapted to studies of this kind.

Peach breeding is being earried on with 3,400 trees now in the plantafion and with about 30 hybrid sedlings now growing in the greenhouse; these latter plants are utilized to the fullest extent this spring, erossing as many as possible and selfing the balance.

\section{EXTENSION WORK}

The members of the Horticultural Department devote a relatively small proportion of their time to extension artivities, not because there is no demand for such work, but because other and more pressing duties oceupy their time. It will be necessary to increase the staff before this phase of the horticultural work ean receive proper attention.

Irany people are reached thru a large correspondence. Lectures have been received favorably and for the most part eagerly, but have been restricted to a small number of localities.

\section{EXHIBITS}

Three exhibitions are held annually by the department. A Chrysanthemum Show is held in November every year; a Fruit and Vegetable Fxhibit is held in connection with the meetings of the Illinois Horticultural Society, in December; and in April an Exhibition of Floral Arrangements is given by the class in floral arrangements.

In 1916 a Tegetable Exhibit, including charts and pictures, was held in connection with the Vegetable Growers' Convention at Chicago. And during 1916-17, the following exhibits were given by the division of Landseape Gardening: the work of Charles Downing Lay, of New York City; Von Penhallow Henderson pastels; prize drawings from the American Academy in Rome: and an exhibit from the Massachusetts Agricultural College at Amherst. 


\section{PUBLICATIONS}

The following bulletins and circulars have been published by the department since 1901:

\section{BULLETINS:}

61 The Farmer's Vegetable Garden

67 Apple Scab

68 Important Details of Spraying

70 Canker of Apple Trees

7f Bitter Rot of Apples

81 Foreing Tomatoes

98 The Cureulio and the Apple

105 The l'armer's Vegetable Garden

106 Relative Merits of Liquid and Dust Spray

114 Spraying for the Codling Moth

117 Bitter Rot of Apples (Horticultural Investigations)

118 Bitter Rot of Apples (Botanical Investigations)

124 Marketing the Muskmelon

144 Growing Tomatoes for Early Market

15.) Fertilizer Experiments with Muskmelons

17t An Ethicient and Hracticalsle Method for Controlling Melon Lice

175 Lxperiments in Onion Culture

176 The Use of Commereial Fertilizers in Growing Carnations

$18+$ Tests with Vitrate of Soda in the Production of Early Vegetables

18.5 Field Experiments in Spraying Apple Orehards

188 Methods of Fertilizing Sweet Potatoes

189 Parasitic Rhizoctonias in America

196 The Use of Commerciai Fertilizers in Growing Roses

\section{CIRCULARS :}

37 Apple Fruit Rots

39 Directions and Formulas for Spraying

to The Farmer's Fruit Garden

41 Small Fruits for the Northern Half of the State and How to Grow Then

42 Fruit List for Northern Illinois

13 Field Work with Bitter Rot During 1901

44 Fruit Storage Experiments

45 Vegetables for a Farmer's Garden in Northern Illinois

46 The Farmer's Flower Garden

47 The Window Garden

58 Prevention of Bitter Rot

67 Fruit and Orchard Investigations

107 Fruit and Orchard Investigations

112 Control of Bitter Rot of Apples

120 Spraying Apple Orchards for Insects and Fungi

139 How to Grow Muskmelons

154 'The Home Vegetable Garden

160 Some Common Spray Mixtures

170 The Illinois Way of Beautifying the Farm

172 The Blight of Apples, Pears, and Quinces

173 Onion Culture 
176 Practical Helps on Landscape Gardening

182 The Fertilizer Problen from the Vegetable Grower's Standpoint

184 The Prairie Spirit in Landscape Gardening

187 A Serious Disease of Cultivated Perennials Caused by Sclerotium Rolfsii

Publications on the following subjects are now in preparation: field rxpreriments in spraying apple orchards: seed production in apples; applebud selection; vegetable gardening; and the mechanieal effects of sprays on the epidermis of the apple leaf.

\section{NEEDS OF THE DEPARTMENT}

Buildings. With the relinquishing of our claim on the old Horticultural Building and adjacent grounds, now used for military purposes, there are in process of development new out-door field laboratories for courses of instruetion in eommereial oreharding, small-fruit growing, and regetable gardening. These laboratories are lorated on a 320-acre tract at the southeast extremity of the campus. Adequate provision must be made without delay for the drainage, fencing, road-making, and planting of this area. 'This out-door equipment must be supplemented at onee with interior laboratory and storage space, and for this purpose there has been designed the group of three buildings shown opposite page 19. The main building of this group is a structure $160 \times 57$ feet, joined to which is a storage house $70 \times 50$ fect, with stables and machinery space adjacent, $153 \times 36$ feet.

Greenhouses. The increasing demands for instructional work, especially of graduate grade, in olericulture and pomology make it imperative that provision be made at the carliest possible moment for an additional vegetable house $105 \times 28$ fect, and two new houses for the growing of fruits under glass, each structure to be $105 \times 28$ feet.

Similarly the increased registrations in floriculture make it necessary to provide at least two new houses in the very near future.

Each of these five houses will cost approximately $\$ 3,500$, making a total of $\$ 17,500$. The florienltural work of the University will never be adequately developed until there is provided the large palm house referred to in former reports.

Research. The most pressing need of the department in the field of leseareh at the present time is the securing of a thoroly trained pomological rhemist. and a plant patholouist and physiologint, each to devote his eutive time to experimental problems relating to fruit growing and vegetable gardeninug. Similar appointmonts have already been made and satisfactory cruipment provided in the division of Florienlture.

Landscape Gardening. The demand for instructional work in landscape gardening and the necessity of greatly expanding our extension activities in this field make it absolutely necessin ry that additional quarters he provided for this work. Three new men must also be added to this work the coming year. 



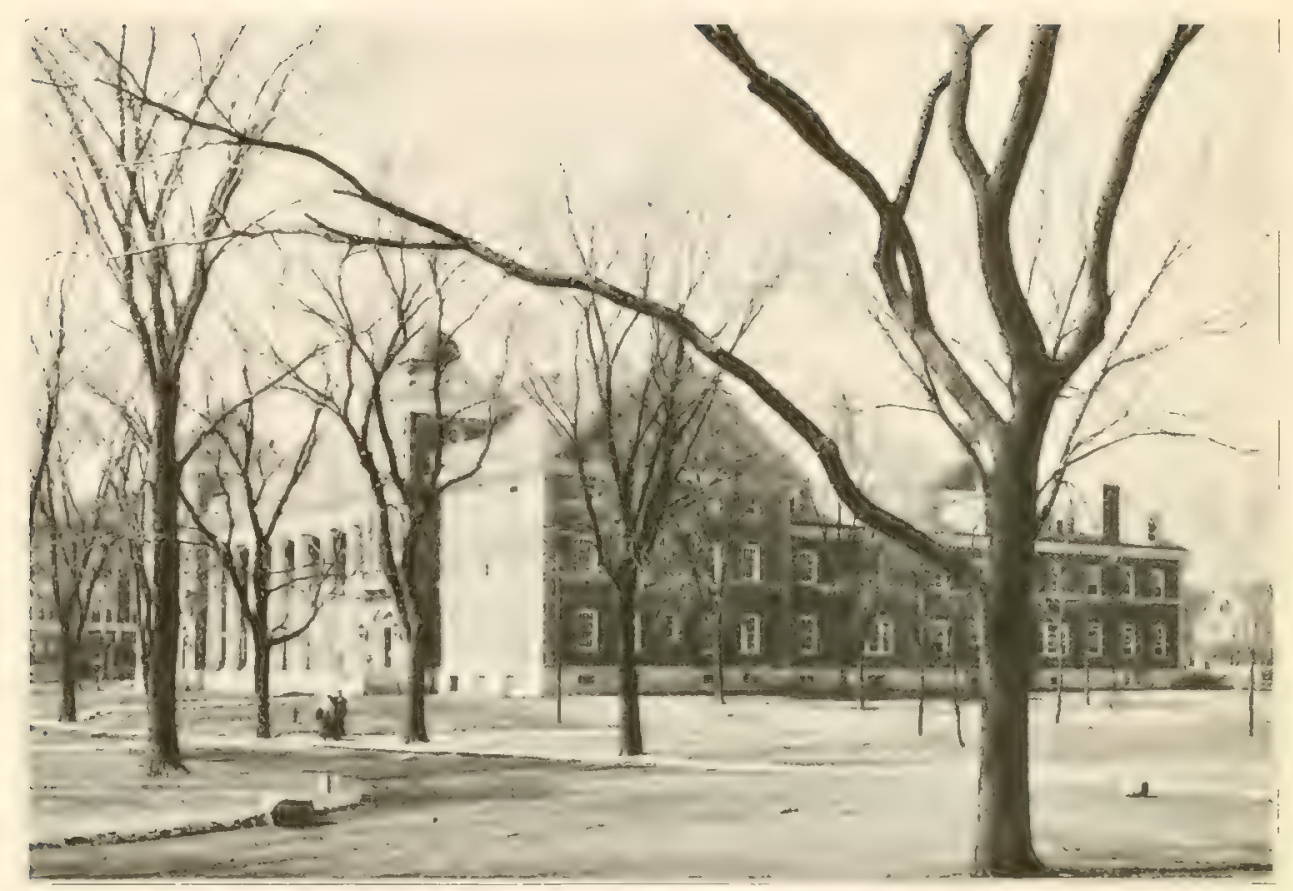

IHE WOMAN'S BCILI)ING

In the north wing of which are located the classrooms and laboratories of the Huusehold Science Department 


\title{
THE HOUSEHOLD SCIENCE DEPARTMENT
}

\author{
Prepared by Isabel Bevier, Head of Department
}

$\mathrm{T}$

HE Houschold Science Department of the University of Illinois is instrueting 525 young women in the principles and processes of homemaking and housekceping. For convenience, the work is arranged under the sanitary, esthetic, and economic aspects of food, elothing, and shelter. But whatever the method of approach, two fundamental conceptions obtain: first, that housekecping and home-making is big business whether one considers the eapital invested or the ultimate good of the individuals concerned; second, that it requires for its successful prosecution, training in the processes involved in housekceping and a knowledge of the materials to be used.

Each passing year emphasizes more strongly the necessity for skilful buying, for careful expenditure of energy, time, and money, both within and without the home, but the neessity for cherishing the less tangible elements of individual and family life is quite as imperative if not so evident. So it is a matter of congratulation that the department has strengthened its work for the family by the addition of a worker trained in economies who, therefore, can consider the family not only in its social but also in its economic aspects.

Two hundred and thirty-six young women are working with food, some in selection and preparation, others practicing housekeeping in the apartment, and yet others studying luneh-room management in the preparation of food for the eafeteria (in which the average daily attendanee for the month of February was 317). This shows that the department itself is a grat laboratory for the study of the many phases of the food supply, such as suitable diet for old and young, sick and well, the cost, selection, and preparation of food, as well as a place in which the student learns both theory and practice.

The world is slowly but surely coming to recognize the value of beauty in common life, which means bringing art into the daily task. The art side of the work of this department is concerned, not only with teaching the value of textile fibers in order to make the woman a successful buyer in these lines, but also with showing her the value of form, line, color, and design as applied to either the clothing of the fanily or the furnishing of the home, to the end that the home and its furnishings shall be not only useful but beautiful. At present, 280 girls are studying along this line.

No small amount of energy goes into the training of teachers. At present, 78 young women of the senior class are doing their practice teaching, under supervision, in the schools of Champaign.

While the larger number of women find their places ultimately in the home, many of them reach it thru the occupation of teacher, the dietitian. the social worker, the lunch-room manager, or the interior decorator. The 
offerings of this department, therefore, as outlined in the 18 undergraduate, 4 graduate, and 6 Summer Session comrses, are plamned to give the student the fundimental knowledge and the method of attack of the problems incidental to these lines of work as well as to those of the home-maker.

\section{STATISTICS SHOWING PRESENT OCCUPATION OF GRADUATES}

The following statisties show the different kinds of work in which our 305 graduates are engaged at the present time:

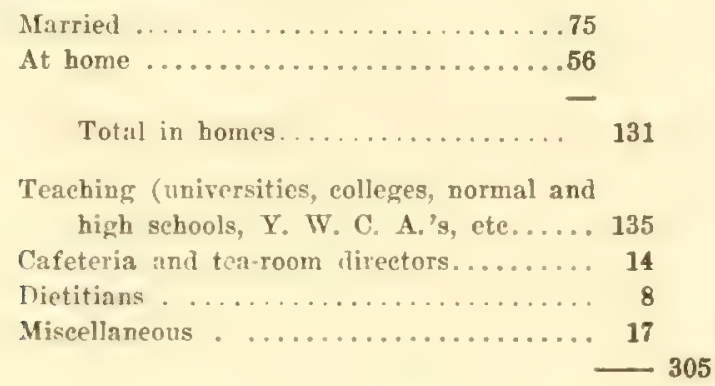

\section{GROWTH IN ENROLLMENT}

The following figures are indieative of the growth of the past five years. and therefore helpful in plans for future growth:

$\begin{array}{ccc}\text { YEAR } & \text { STUDENTS } & \text { FACOLTY } \\ 1912-13 & 358 & 9 \\ 1913-14 & 406 & \\ 1914-15 & 421 & \\ 1915-16 & 469 & \\ 1916-17 & 525 & 16\end{array}$

In other words, the gain in students in this department during the past five years has been 45 pereent, and for the past biennium, 25 percent. while the undergraduate courses have increased from 16 to 18 and the Erarluate courses from 2 to 4 . The growth is further evidenced by the fact that thres-fourths of the graduates belong to the last five rears, and that the vass of 1917, numbering 93 , is more than three and one-half times as erealt as the class graduated in 1912. Then the regular instruetional staff numbered 9 , at present it numbers 16 .

This increase in enrollment and in graduates indicates that the people of the state have a growing interest in home and family life and in the training of women to meet the different phases of the problem.

\section{EXTENSION WORK}

The extension work of the Household Seience Department is particularly important becanse it deals with questions vital to individual and community life, in fact with their very essentials - food. clothing, shelter, and health. The agencies employed are: 



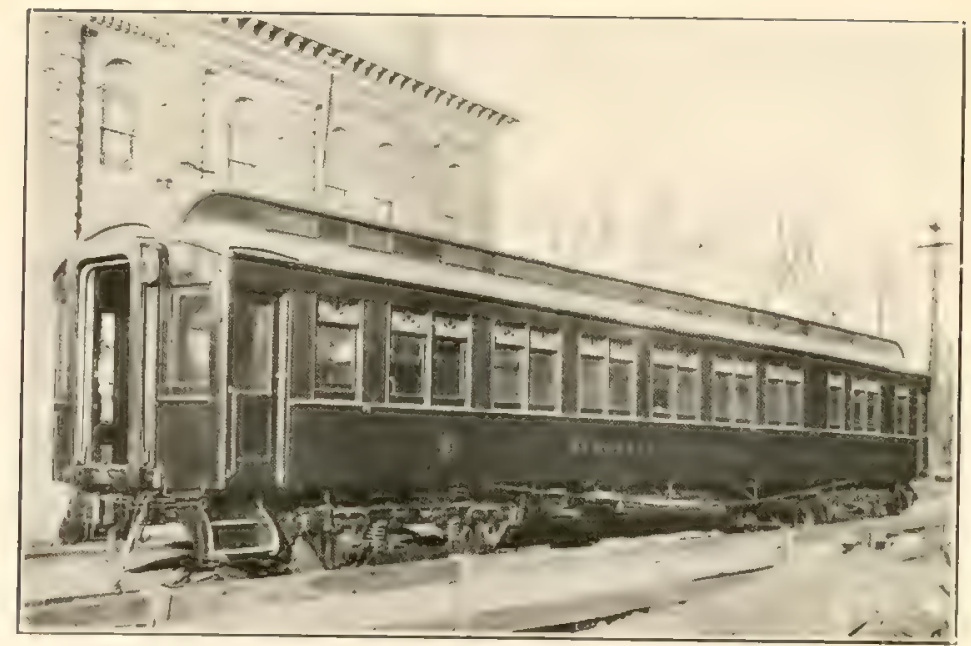

HOME ECONOMICS DEMONSTRATION CAR

Shows types of light, heat, water, and power installations for the country home; also types of furnishings and equipment

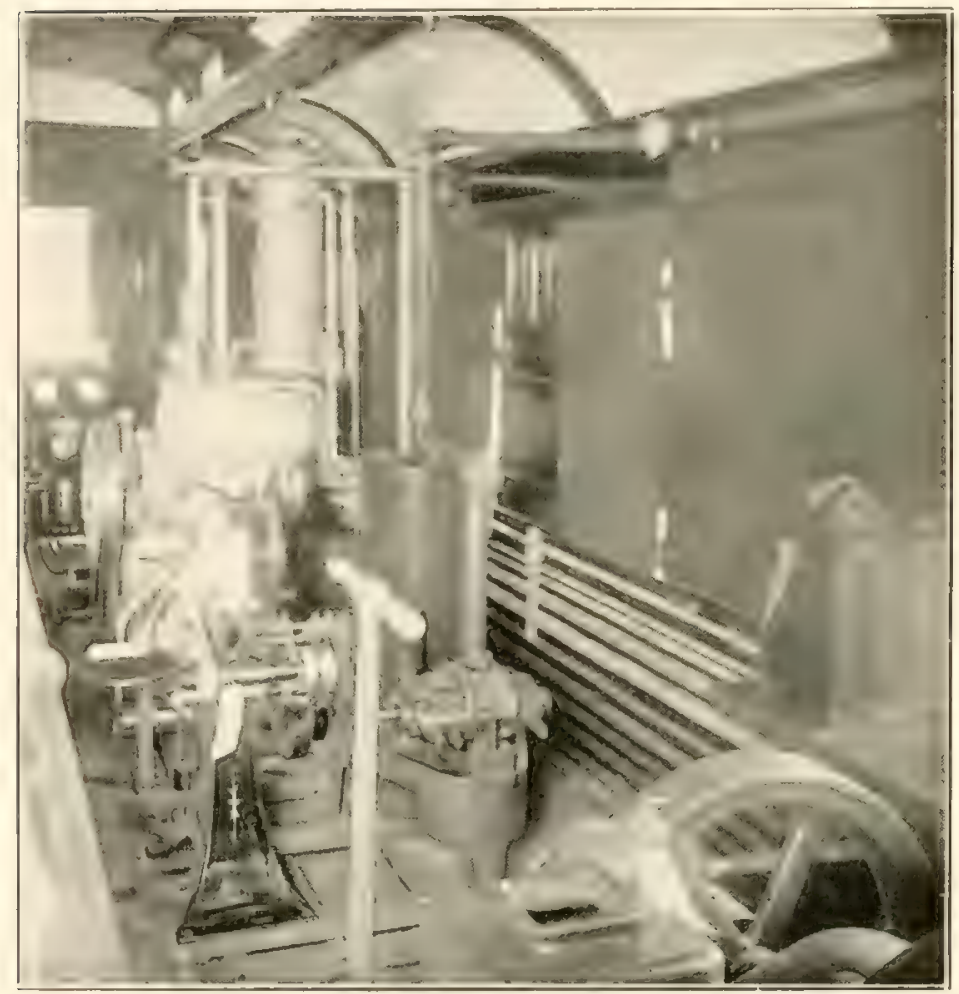

POWER MACHINERY IN DEMONSTRATION CAR 
1. Correspondence

2. Service for organizations, such as the Farmers' Institute, Parents' and Teachers'Associations, ete.

3. Movable Schools

4. Demonstration Car

5. Sehool for Housekecpers

This extension service is announced by a special circular and can be had by any community upon request. The work is condueted by a regular staff of six, supplemented, becsuse of the large number of ealls, by six part-time workers. Almost every phase of home life has been presented by these workers in 31 movable sehools and 88 lectures given from July 1 , 1916, to January 1, 1917. It seems probable that the total attendanee at the schools and lectures this year will be cousiderably in excess of the 50,000 attending last year. The following figures give the numbers served from July 1, 1916, to January 1, 1917.

By separate lectures and demonstrations...........12,648

By Morable Schools ...................... 7,926

By Demonstration Car (November and December only) . 4,152

Total for $\operatorname{six}$ months.................. 24,726

Letters and cards sent out-in regular correspondence... $\quad \mathbf{1 , 5 5 8}$

Bulletins sent out...................... 18,817

Numbers served for the month of January, 1917 :

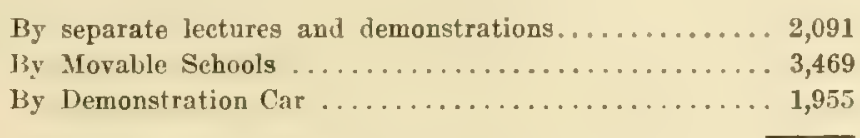

Total away from the University........... 7,515

School for Housekeepers at the University.......... 657

Total for month of January............. 8,172

\section{PUBLICATIONS}

The following bulletins are written for the benefit of housckeepers and teachers, and aim to present simply and clearly the scientific results as determined in the laboratory.

The Principles of Jelly Making

Some Points in Choosing Textiles

Some Points to be Considered in the Planning of a Rational Diet

Some Points in the Making and Judging of Bread

The Cooking of Carp

The Service of Meals

The Planning of Meals

The Rural School Lunch

Syllabus of Domestic Science and Domestic Art for the High Schools of Illinois 
Outlines for Work in Domestic science and Domestic Art for the Elementary Schools of Illinois

Announcement of Extension Service in Houschold Science

Home Economies Demonstration Car

\section{SPECIAL FEATURES OF EXTENSION WORK}

Three features of the extension work deserve special mention-the health work, the demonstration ear, and the county adviser.

The health work is conducted by a woman trained in home economies and in nursing. It deals with questions of home sanitation, personal hygiene, emergencies, first aid, and the care of the mother and child. When statistius show that the death rate of ehildren is higher in the country than in the slum districts of our crowded eities, it is time something were being done for the country child. In order that the Household Science Department may be ready to do its part in the event of war, this instructor has prepared to give the work outlined by the Red Cross organization, and is whering work in the summer sission under the name of C'ommunity Health. 1) uring the year January 1, 1916, to January 1, 1917, she delivered 225 loroures and demonstrations in :':2 eomies of the state.

\section{HOME ECONOMICS DEMONSTRATION CAR}

'The Household Science Department has equipped a demonstration car which is at the service of any community of the state.

This ear marks a new departure in extension work. Hitherto, demonstrations in Home Eeonomics have been confined largely to the cooking of food. It is the purpose of this car to extend this method of presentation to power equipment and house furnishings; to actually show machines, kitchen utensils, and color schemes, not just to talk about them.

In accordance with this idea, this ear shows how power eommonly used upon the farm may also be employed in performing a large part of the heary labor of the home; how to secure an adequate watel supply for both the house and barn with the necessary provision for sewage disposal; and, finally, how, by attention to equipment and to the principles of form and color, the essentials of comfortable living may be secured for the country home at a reasonable cost.

The equipment consists of :

1. A gasoline engine operating the washing machine, mangle, eream separator, vacuum cleaner, ice eream freczer, etc.

II. Installation of a hot and cold water system under pressure for house and barn, operated by the same machine.

III. Electric lighting system for private home.

IV. Septic tank and sewage disposal.

V. House furmishings. This includes a great variety of furnishings from kitchen utensils to furniture and color schemes for the living room 


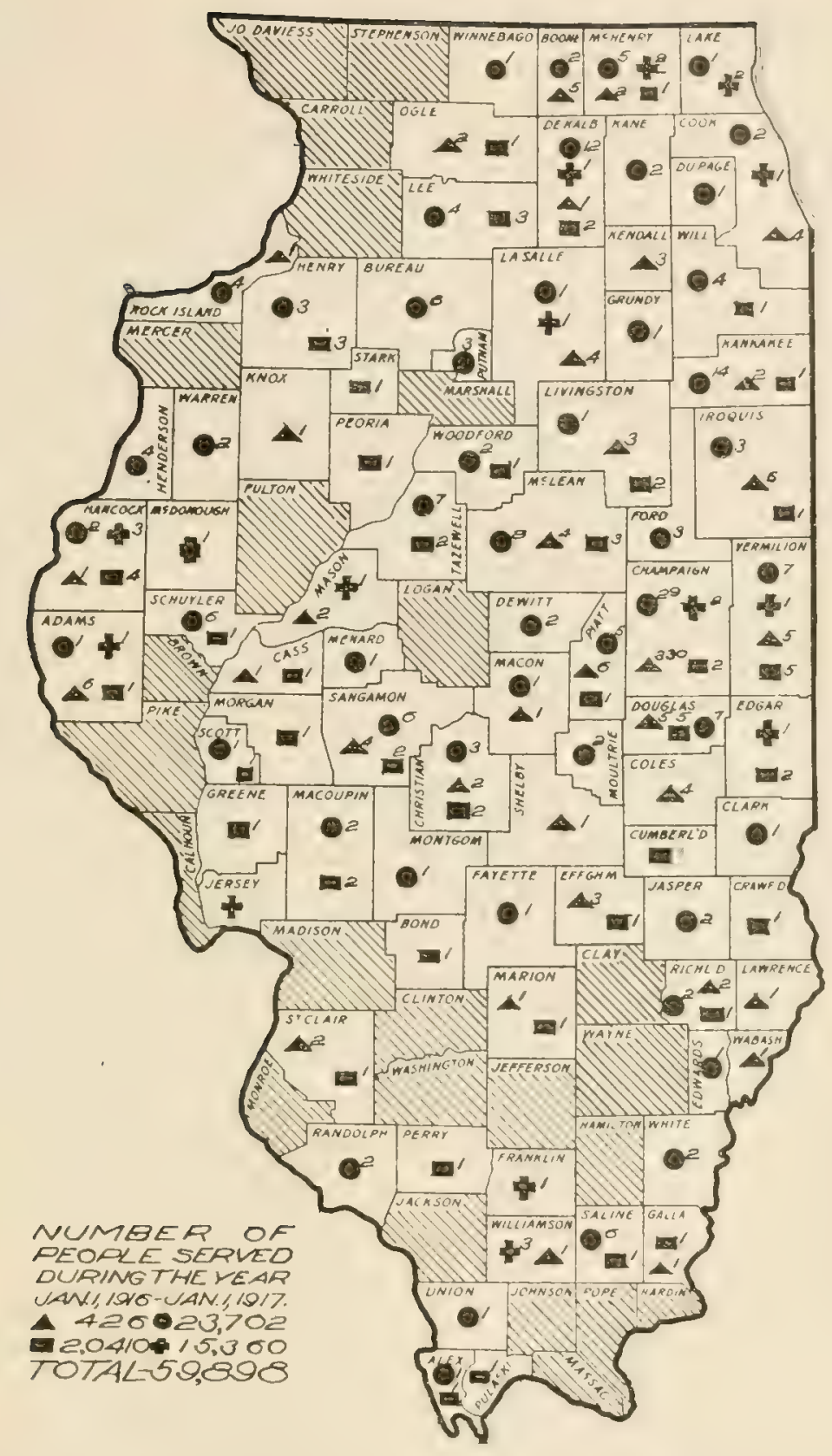

A COUNTIES AEPRESENTED AT SCHOOL FOA HOUSEKEEPEPS - WITH FIGUPES, INOICATES NUMBEA OF SEPARATE LECTUPES - WANO OEMONSTPATIONS a STRATION SCHOOLS.

TH WIT FIGURES INDICATES NUMBEP OF WEEWS OF DEMON I WTARTION CAR SEAVICE

MIIIU COUNTIES HAVING NO SEAVIEE. 

and the bed room, so that the housekeeper may sce how. if care is given to color, texture, and quality, a house may be furnished attractively at a reasonable cost, and also how time and energy may be saved by the wise selection of utensils and by system in their arrangement.

The car and its equipment provide sufficient material for demonstration work for a week. It is designed to reach housekeepers under conditions favorable to a thoughtful study of the equipment, so it is not feasible to use the ear in commection with a movable school, a farmer's' institute, or as an addition to other enterprises. It is proposed to spend five days at a point. The general plan is to have the ear open each morning for inspection with two demonstrators to explain the equipment; to have a demonstration each afternoon, and a lecture in the evening in a suitable hall. This arrangement of time leaves opportunity, if desired, for the demonstrators to visit a farm home for the purposes of inspection and suggestion.

The work of the demonstration car and of the county adviser are conducted under the provisions of the Smith-Lever Act and in cooperation with the United States Department of Agriculture. The ear seems the best possible way of carrying to the rural communities ideas and suggestions for home equipment.

\section{COUNTY ADVISER IN HOME ECONOMICS}

It is a matter of congratulation that Illinois was the first of the northern states to undertake the maintenance of a county adviser for women. This work is conducted in cooperation with the women of Kankakee county under the name of the Home Improvement Association. It is now in the second year of its development and bids fair to add a substantial increase to the 6,000 people served last year.

\section{NEEDS OF THE DEPARTMENT}

The statement of the work now in progress makes very evident the great need of the Department-adequate provision for maintenance and growth, so that by the time the last year of the biennium is reached there will remain sufficient funds to meet the increased demands due to growth. As a matter of fact, the expenditures for this year have been reduced to the buying only of that which was absolutely necessary for student use. Investigation, publication of extension bulletins, and the purchase of equipment of all kinds, have been postponed because the funds have necessarily been expended in caring for the increased demands for student instruction.

The Woman's Building serves as an attractive and convenient laboratory for the Household Science Department. It will afford sufficient space for another biennium, but the equipment both of faculty and of materials must be greatly enlarged in the immediate future if this Department is to meet its responsibilities and opportunities for service in the homes and health of the people of Illinois. 


\section{SMITH-LEVER EXTENSION}

FRONI the first the outside activities of the College of Agriculture have been very great. Members of the faculty have been called upon to attend thousands of mectings and discuss with farmers the progress of investigations and the newer methods of agricultural practice. So has deep cultivation of corn been made to give place to shallow cultivation; so has exhaustion of the soils of the state been arrested by a better care of our stock of fertility and the establishment of a really permanent system of agriculture.

The value of this outside work has been widely recognized. Until recently it has been mostly promoted by people already overworked in the classroom or the laboratory, but in the spring of 1914 Congress passed what is known as the Snith-Lever extension bill by which was established in every state of the union a definite demonstration service hoth in agriculture and in home economics.

The amount to come to Illinois from the federal treasury under the Smith-Lever Aet for the coming year is $\$ \$ 0,085.86$, which is available for demonstration service, mainly under a system of county advisers supported jointly by the lueal associations and this fund. Under this plan twentythree counties are now in full operation, with advisers whom they themselves have employed after mecting three conditions imposed by the College of Agriculture, which is made the rustodian of the Smith-Lever fund. The three conditions are that the advisel must be a college craduate; that he must have actually lived upon the farm for at least five years; and that he must have had at least five years' suecessful experience in some line of agricultural work since graduation.

The Snith-Lever work in home ceonomies has already been outlined in the Household Science section of this report. 



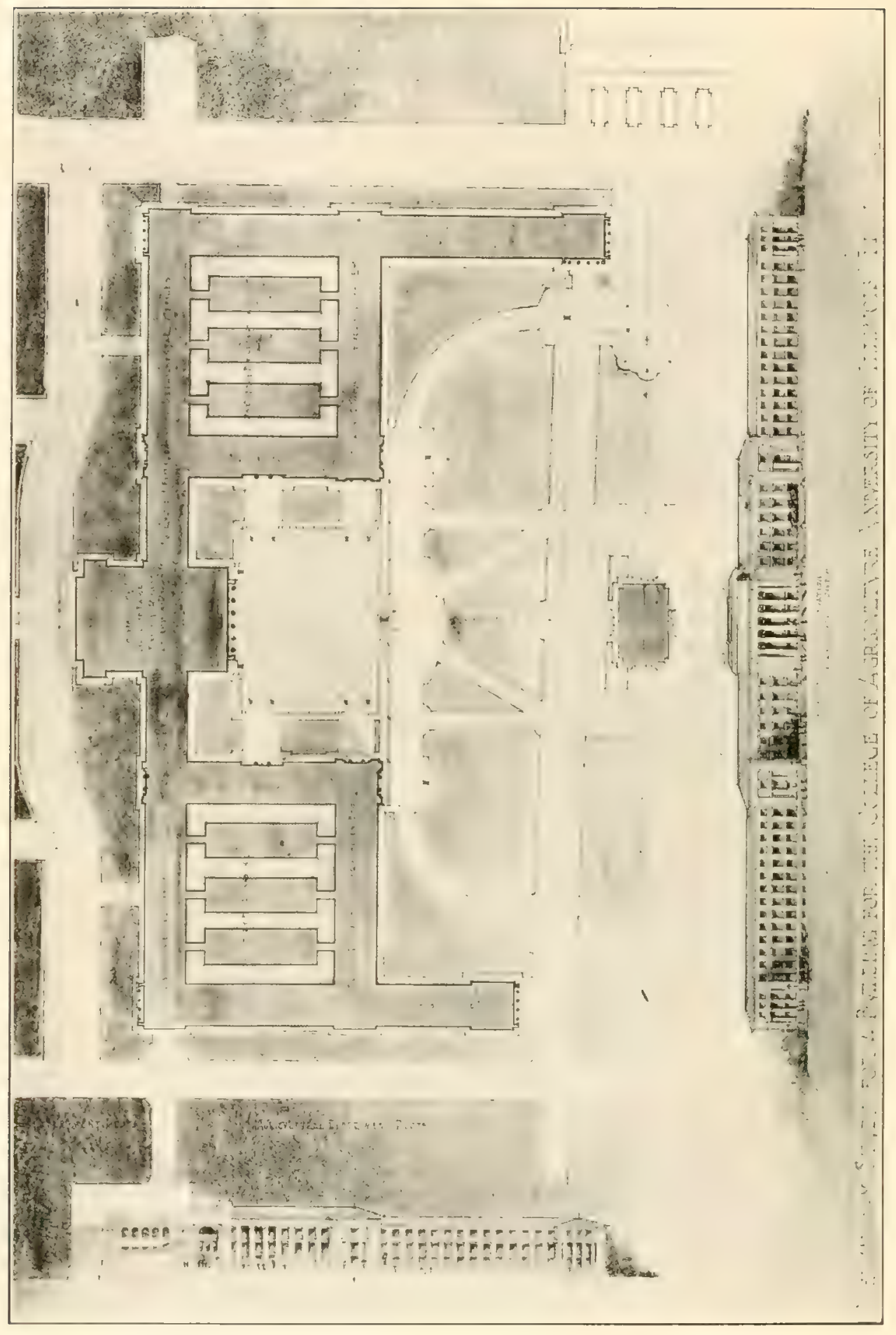




\section{WHAT THE AGRICULTURAL COLLEGE AND EXPERIMENT STATION NEED}

$T$

$\mathrm{HE}$ growth of the agrieultural work of the University has been beyond all expectation, and the demands upon the institution have overtaken and are far exceeding its facilities. What the institution needs in order to meet these demands is:

First. A stronger faculty

Second. The strengthening of certain lines of work

'Third. Additional room

\section{A STRONGER TEACHING FACULTY}

The real teaching power of the agricultural faculty is greatly reduced by the fact that over one-third of the staff must give their entire time to the work of the Experiment Station, extension, and administration; while some three-fourths of the remainder give part time to experiment station work, extension service, or graduate study. Effective service in the classroom is still further reduced by the fact that much of the equipment of the College of Agriculture is in fields and herds that require a very great amount of labor in their proper care.

The actual result is that even tho men are overworked, they are still unable to give sufficient attention to the student body. The only relief is a substantial addition to the number of the agricultural staff.

The University of Illinois has been slowly beating its way uprard among the institutions of the country in paying salaries sufficient to hold in its service the picked men of the faculty. In this it has been fairly successful, especially in later years, but new conditions are bringing new demands, and unless the resources of the College of Agriculture can be substantially increased, we shall be unable to maintain that tested body of teachers and investigators without which the Tniversity would be unable to render satisfactory service.

It is inevitable that a considerable portion of a faculty must consist of young and inexperienced people still in the list of learners, because in no other way can instructors and investigators be trained. It is also inevitable that if these men are to live normal lives, they must be paid, even while completing their education and training, salaries sufficient to provicle the neessities: otherwise the supply of faculty material will be cut off at its somrce.

Until the present time we have been able to sccure these young men at very moderate salaries, so moderate that the wages now paid to janitors frequently equal and in some cases exeeed salaries paid to assistants. Clearly, the increased cost of living indicates that something must be done at this point. Besides, a new competition is springing up from neighboring institutions. 
If there were a reliable and adequate supply of faculty material, the institution would be fleed from mueh embarrasisment in the training of teachers and investigators, and the service could be much nore cheaply and effectively rendered, but such a supply does not exist and the University of Illinois, like all other of the larger institutions, has no choice but to do its share in the preparation of teachers and research men.

\section{THE STRENGTHENING OF CERTAIN LINES OF WORK}

No marked additions have been made to the offerings in the college or the work of the Faxperiment Station durine the last half dozen years. In the meantime certain stujects have eome to the front which have been either entirely neglected, or undertaken only in a fecble way: for example, Farm Organization and Inamement, involving the study of farming from the standpoint of eenomies rather than of chemistry or binlogy ; rescareh work in Farm Machinery, which has been studied mainly from the standpoint of the designer, not the onerator: Ponltry hnshandry, which is hegriming to be a large subject in a state like Illinois; more exhanstive work in Animal Diseases, particularly with referenee to the instruction of agricultural students in the care of live stock; a considerable increase in facilities for instruction and pesearch in new phases of the Food Problem both from the publie and the private point of view, with further work in IInme NursIng; and extension work with boys and girls in agriculture and home economies both in connection with schools and with local clubs.

Such new and important subjects should be equipped for the best grade of instruction, and in some cases for research as well.

Besides such subjects of generally recognized importanee, there are others, like ber-kecping, whivh have long presect upon the attention of the University and which have been neglected for no other reason than lack of funds. Vast amounts of honey are going to waste in the forests and fields simply because a suffieient stork of bees is not maintained for its gathering. Seanning our possible l'wouress in this fashion, we should find many other enterprises which ought to be seriously undertaken, but the problem is so vast that only the most pressing needs can be met at the present time. Even so, considerable additions of funds are necessary.

In a very considerable sense the Acricultural c'ollege and Fxpreiment Station have been marking time in recent years. The present budget, cxelusive of buildings, is but 5 perent higher than the budect four years ago; whereas the student registration has increased 32 pereent, the agrieultural faculty 27 pereent, the erakunting elass 136 pereent, and the graduate students 200 percent.

In order to live with the situation at all, we have been forced to close certain classes against additional students cren on the first day of registration, and we have been ohliged to wreatly rlonere the conditions for graduation in order to give the students wider liberty in finding courses not 
filled and which might be offered for credit. We have about reached the limit even of these devices, and something significant will have to be done without delay if the College is not to be injured and students actually turned away.

To strengthen the faculty and enable it to ineet the increased demands in both old and new lines of work, and to provide proper equipment for the same will require additional funds to the amount of not less than $\$ 125,000$ annually.

\section{ADDITIONAL ROOM}

Six years ago upon the recommendation of a committee of citizens which visited half a dozen other institutions, the Trustees of the University asked the Legislature for $\$ 337,500$ for an addition to the Agricultural Building. During the session it became necessary to sacrifice either this asking or the incrcased funds for maintenance. With the conditions threatening, the building was sacrificed in the interest of caring for students, hoping that space would make itself available. The wisdom of this move was shown by the fact that since that time (1911) the student attendance has increased ovel 64 perent. Without the funds plovided at that time, it would have long ago become necessary to turn away agricultural students.

We have, however, been pressed for room even beyond our anticipation six years ago.

In spite of additional space provided in the new Stock Judging Pavilion and the Floricultural laboratories, we have been obliged to roof over the court of the Agricultural Building and also erect a temporary structule for geneties. After doing this, we have overflowed into all sorts of available buildings, cven into private houses, until the offices of the College of Agriculture are seattered in ten different buildings upon the campus-from Springficld avenue on the north to the Stock. Judging Pavilion nearly a mile to the south. ('learly, this seattered condition makes the best work impossible.

\section{UNABLE TO SERVE STUDENTS}

Besides, we are unable properly to serve the students. The laboratory equipment of certain courses is so far below the present registration that many students are unable during their entire sojourn to get the instruction they came especially to receive.

The inevitable result of such a condition of things is best pointed out by calling attention to the fact that since 1900 there has been an average ammual increase in students of 65 , in recent years approaching and sometimes exceeding $100(1912,100 ; 1913,76 ; 1914,109 ; 1915,170 ; 1916,71)$, until the present year, in which the registration has fallen off something more than 50. When an annual increase of approximately 100 becomes a decrease of 50 , it is time to consider the conditions and take stock 
of the situation. partienlarly when the registration in the University as a whole has increased during the present year as in other years.

It is of course impossible to state to what causes this decreased attendance is duc, but remembering that the attendance in the institution as a whole has increaser? while that in Agriculture has suddenly decreased after sixteen years of rapid rise the suspicion is well founded that our inability to meet the demands of the students as they meht to be met is responsible for at least a goud proportion of this decline. barticularly as the lecline set in last year (the increase being 71 as compared with 170 and 109 in the two former years). Students have noticed these limitations to our work and have been talking about them for three or four years. As this condition becomes chronic, it eammot but deter students from coming or send them to other states.

\section{POSSIBILITIES FOR RELIEF}

There are but three things that ean be done to relieve the situation:

First. Limit the attendance of students, frankly cutting down the number to those that can be accommodated under present conditions.

Second. Put up temporary structures to be wrecked after a few years.

Third. Provide at the carliest possible moment propely construeted permanent buildings.

Clearly, the public would not approve the policy of turning away students. The construetion of tempurary buikings to be wrecked in a few years would only postpone the problem, not solve it. The erection of anything but permancut huildings is not feasible: first, beeause. with valuable records, the fire risk in any but permanent buildings is too great; and second, because the repair of such buildings under the heavy uses of a university soon comes to cost more than the buildings are worth.

\section{THE ONLY FEASIBLE SOLUTION}

The only foasible solution is a fire-nunf construction of the most durable sort. plain in its arehitweture hut alapted to the purposes of university work.

Inasmuch as the present Agricultural Building stands on a portion of the campus which in the growth of the University is needed for purposes other than agriculture, this plant should be ereeted upon the South Campus. and it shonld be lange enomeh to shelter the entire classioom, laboratory, mat offine needs for both the college of Agrienlture and the Experiment Station. To do this it must provide not less than 300,000 square feet of floorspace, which for fireproof, permanent, and creditable construction according to arehitects' estimates will cost $\$ 2,000,000$.

This is a very large sum of money; but when it is remembered that the Massachusuts Institute of Terhublow has just invested $\$ 7,000,000$ in an

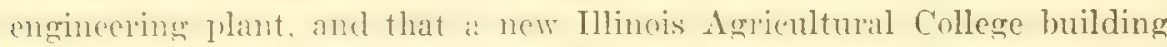
should talie (are of the chucitional needs of mole than 2.000 students, with offices, laboratories, library, and other equipment for faculty work, the amount is clearly a minimum. 




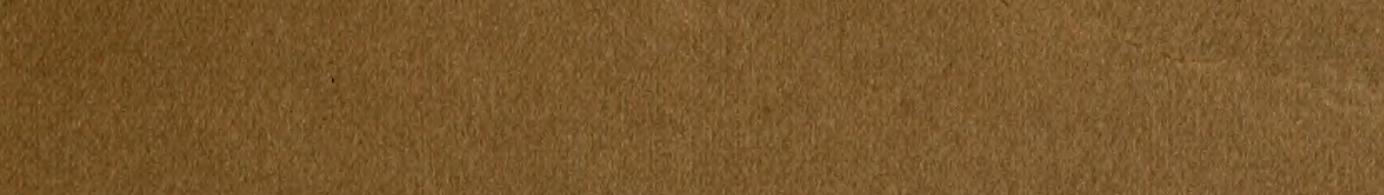
thes nis 6)

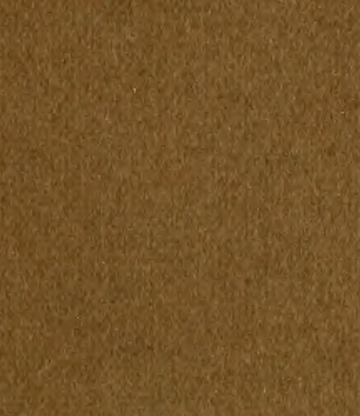

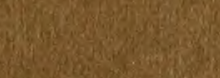

3.

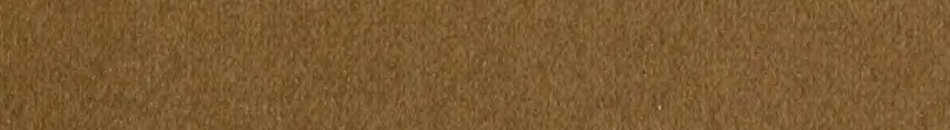
3. H.1. 6.

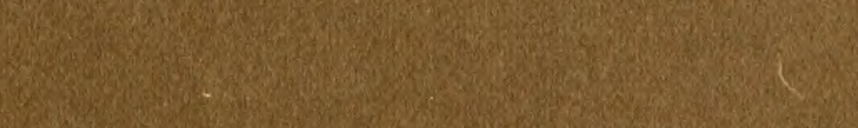

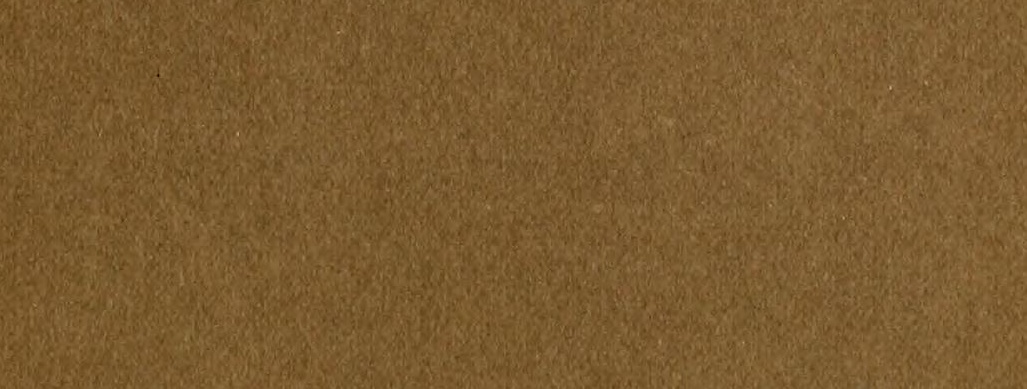
3.2.

$x^{2}+x^{2}+x^{2}$

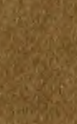

Whe

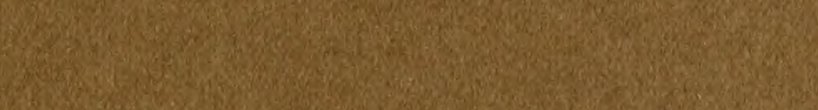

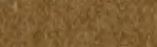

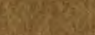
Whate

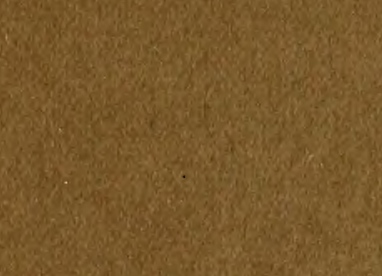

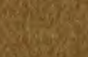
2.

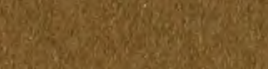
and

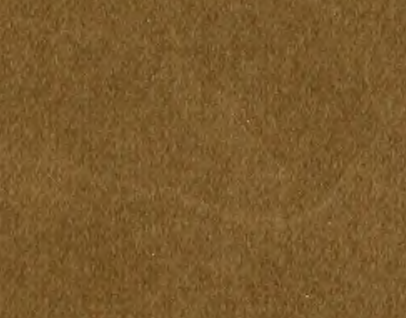

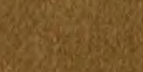
acicis

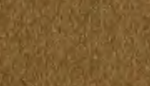
2.0.

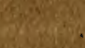

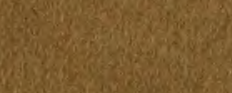
2.

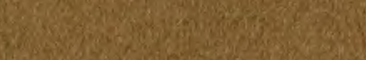
W. Qn

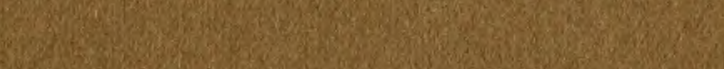
(6) Fin

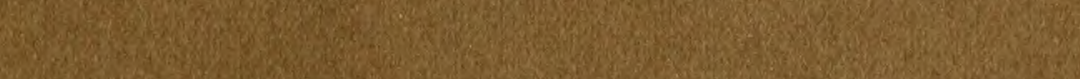
-

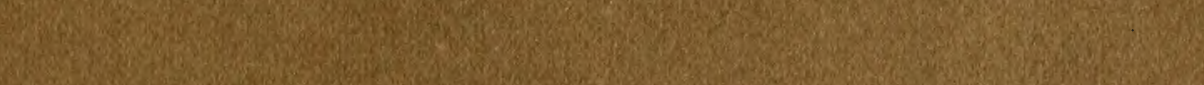

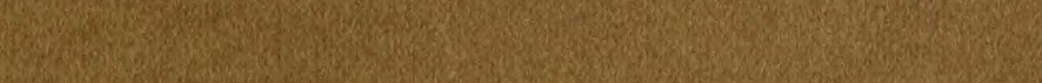

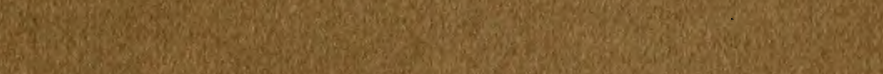

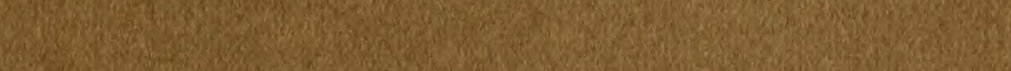

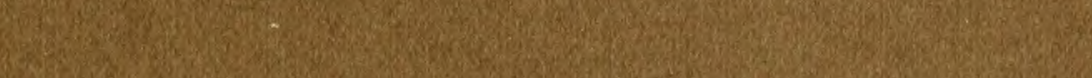

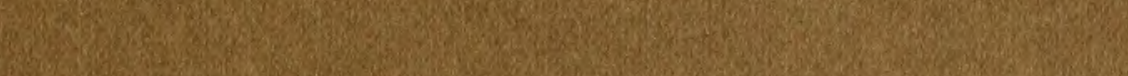

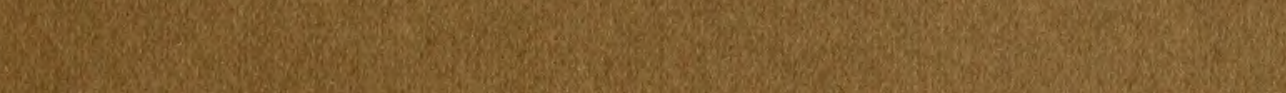


